\title{
AMBER DISCS WITH CROSS DECORATION
}

\section{ADOMAS BUTRIMAS, REGINA ULOZAIT $\dot{E}$, MARIUS IRŠ்́NAS}

\begin{abstract}
Amber discs with cross decoration are the research subject of this article. The article discusses their proliferation, typology and chronology. The amber disc from the Daktariškè 5 settlement is analysed in greater detail: its decoration, the number of holes, regularities, spectral analysis and possible symbolic meanings are discussed.
\end{abstract}

Key words: amber discs, cross decoration, Stone Age, Baltic region, spectral analysis, residues in a pit.

DOI: http://dx.doi.org/10.15181/ab.v25i0.1835

\section{Introduction}

The warmth, magnetic quality, and colour of amber seem to require that this substance embodies very important meanings. Since time immemorial, the sun, the universe and the human model of the world have come to be imagined in the eastern Baltic region via amber artefacts, especially amber discs. Quite a large number of amber discs made during the Neolithic period have been found in what is now Lithuania, Poland, Latvia and neighbouring countries, but they usually just have an evenly polished surface without further any decoration. The spread of amber discs with a cross decoration is quite clear. The area across which they are distributed is bounded in the north by western Lithuania (Juodkrante, Daktariške 5, Palanga, Šventoji, Būtingè), and in the west by the region around Stupsk (Stolp) in Pomorze and the environs of Torun, slightly to the west of the Vistula. Its southern boundary lies in the area around Warsaw and Lublin, while to the east these artefacts spread as far as the Iwanie site of Rivne (Ukraine). The greatest concentration occurs in the Mazurian Lakeland. Here they are found most commonly in Globular-Amphora culture graves (Šturms 1956, p. 17). However, one special example was found in the Daktariške 5 Neolithic settlement. It appears to bear special coded and very well preserved information, unlike any other artefact found in Lithuania or the rest of eastern Europe. Unfortunately, our ability to understand this information, which comes down to us from almost 5,000 years ago, is extremely limited.

\section{The topography of the settlement}

The Daktariške 5 Neolithic settlement is approximately 2,300 metres east of the bridge across the River Rešketa on the current Telšiai-Varniai road, approxi- mately 1,000 metres to the east of the Daktariške 1 Neolithic settlement, on the southern slope of a hill between Lake Biržulis and Lake Stervas, 50 metres from a drainage ditch not far from the eastern boundary of the village in the Varniai district of Telšiai, Samogitia (Fig. 1). The drainage ditch separates a cultivated meadow and Bagdoniške Hill (on whose southern flank our settlement was excavated) from the low-lying mixed woodland of the marshy Lake Stervas. As is shown by soil bores taken by Rimvydas Kunskas in the environs of the settlement, during the sub-boreal period there was still a shallow fish-laden stream flowing between lakes Biržulis and Stervas.

The settlement was discovered in the autumn of 1986, and excavated in 1987-1990 by an expedition from the Vilnius Academy of Art and the Lithuanian History and Ethnography Museum (now the National Museum of Lithuania).

\section{Cultural layers, stratigraphy, spatial research}

Amber discs, links and half-finished products for producing these artefacts were found in the cultural layer of the Daktariške 5 Neolithic settlement. Two discs, one with a lens-shaped cross-section with cross decoration, and one two millimetres smaller, without decoration but also carefully polished on both sides, were found in trench III. The whole Daktariške 5 settlement was excavated in four-metre-wide trenches of lengths of ten to 16 metres, depending on the cultural layer and the spread of the finds. Trenches I-VI and VIII-XI were dug north to south, only trench VII was dug east to west. All the north-south trenches sloped downwards in a southerly direction (including trench III with the amber discs). Grids running north to south (according to the length of the trench) were marked with num- 


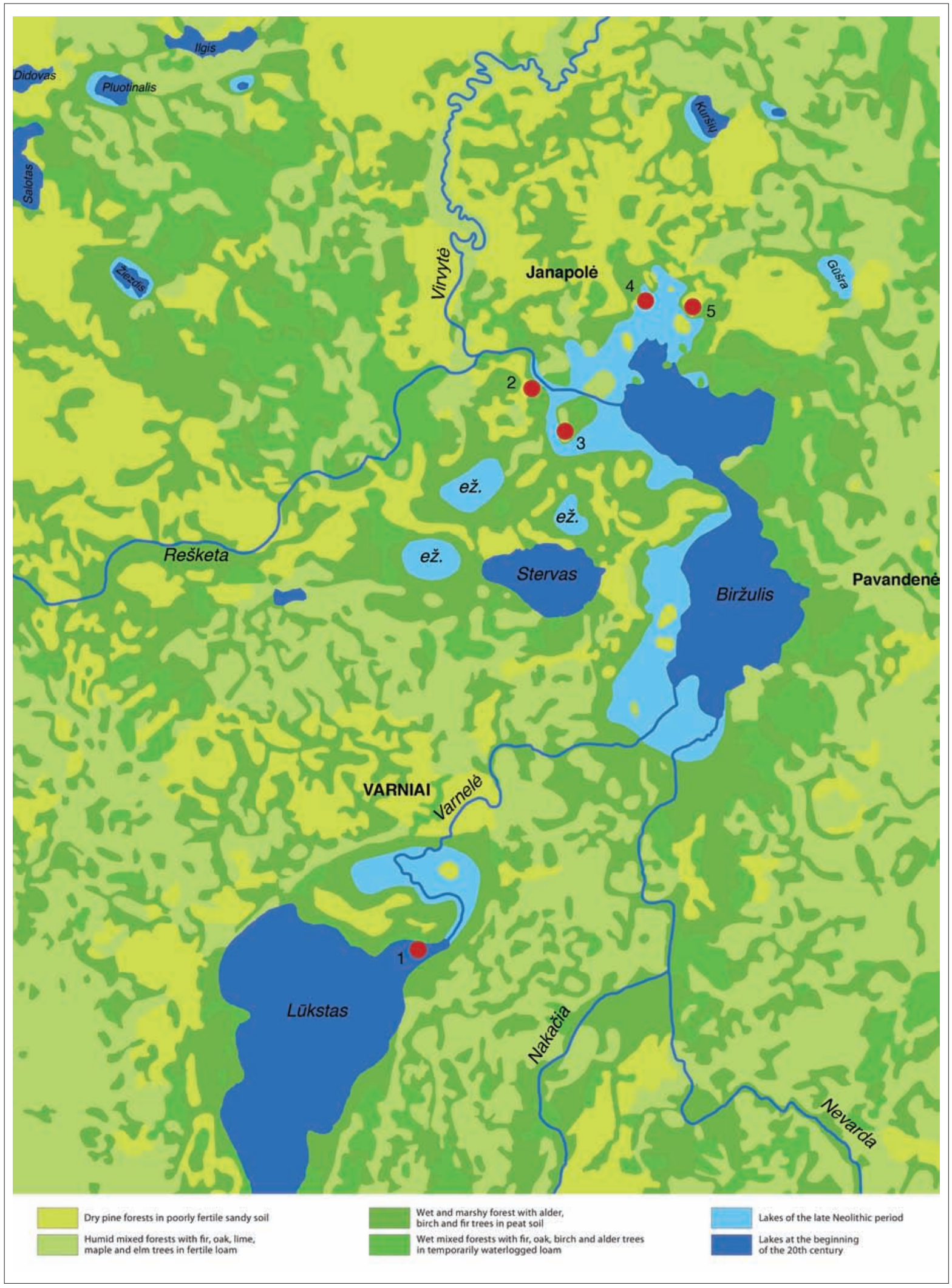

话

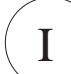

STONE AGE

IN NORTHERN

EUROPE:

CHANGES IN

LANDSCAPE,

TECHNOLOGIES

AND BELIEFS

Fig. 1. A map of Neolithic settlements with amber artefacts in the Lake Biržulis area and the Amber Bay of Lake Lūkstas: 1 Amber Bay in Lake Lūkstas; 2 Daktariškè 1; 3 Daktariškẻ 5; 4 Gaigalinè 1; 5 Kalniškiai 1 (compiled by R. Spelskytè). 


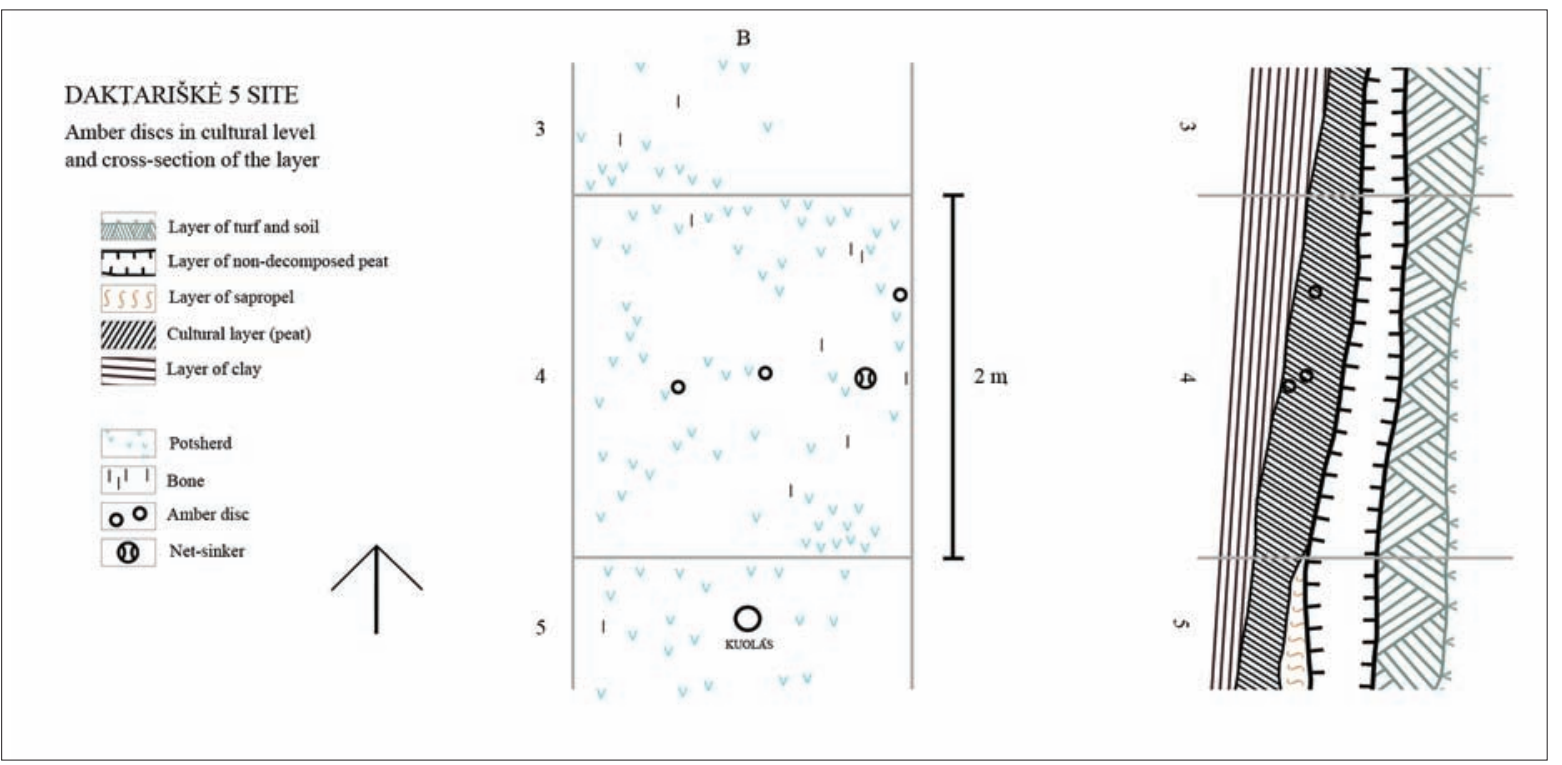

Fig. 2. The investigation of amber discs in the cultural layer of the Daktariške 5 Neolithic settlement and a cross-section of the layer, 1990 (drawing by A. Butrimas).

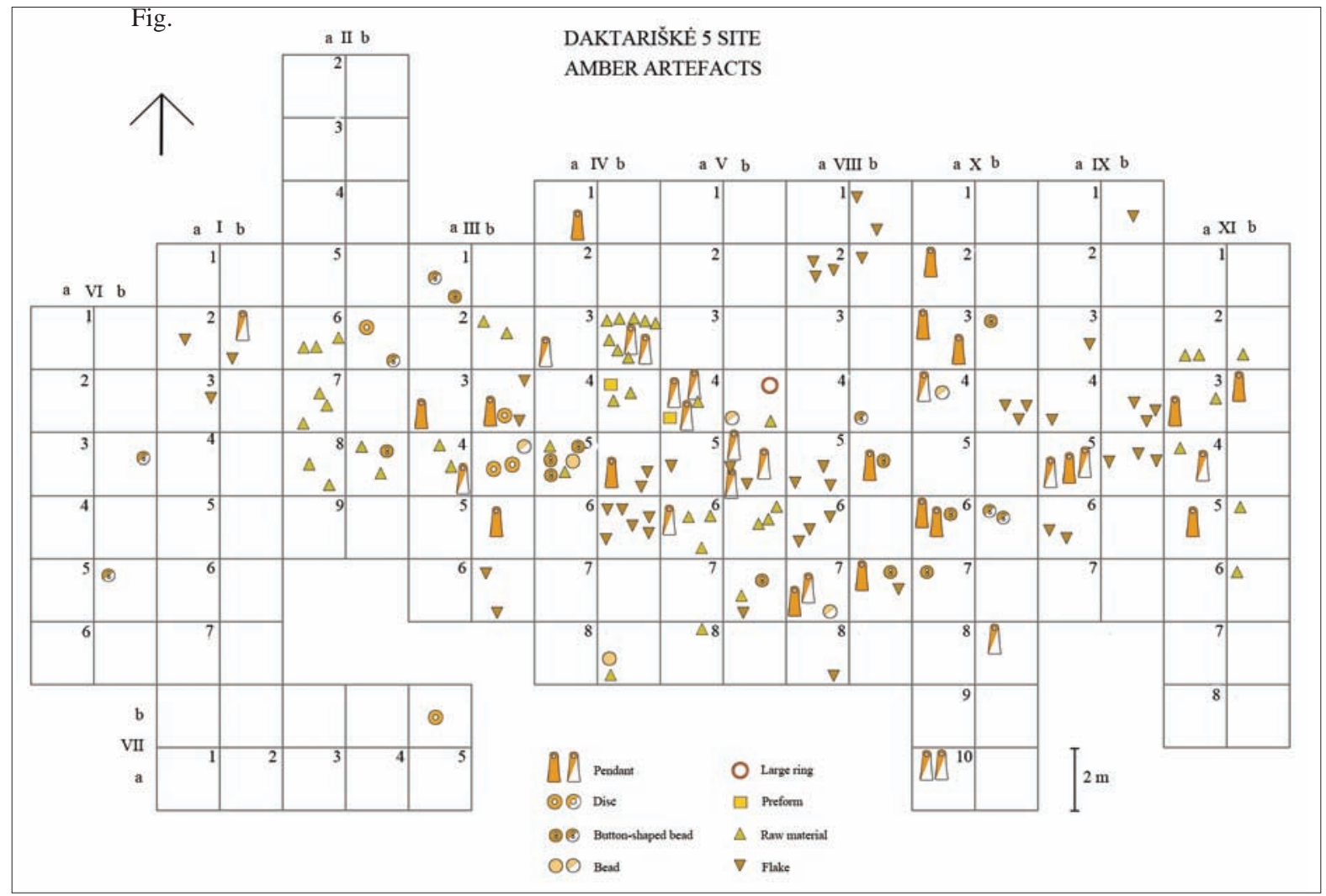

Fig. 3. The distribution of amber artefacts, unworked amber lumps and blanks, and the production waste in the Daktariškè 5 Neolithic settlement (compiled by R. Spelskyte). 


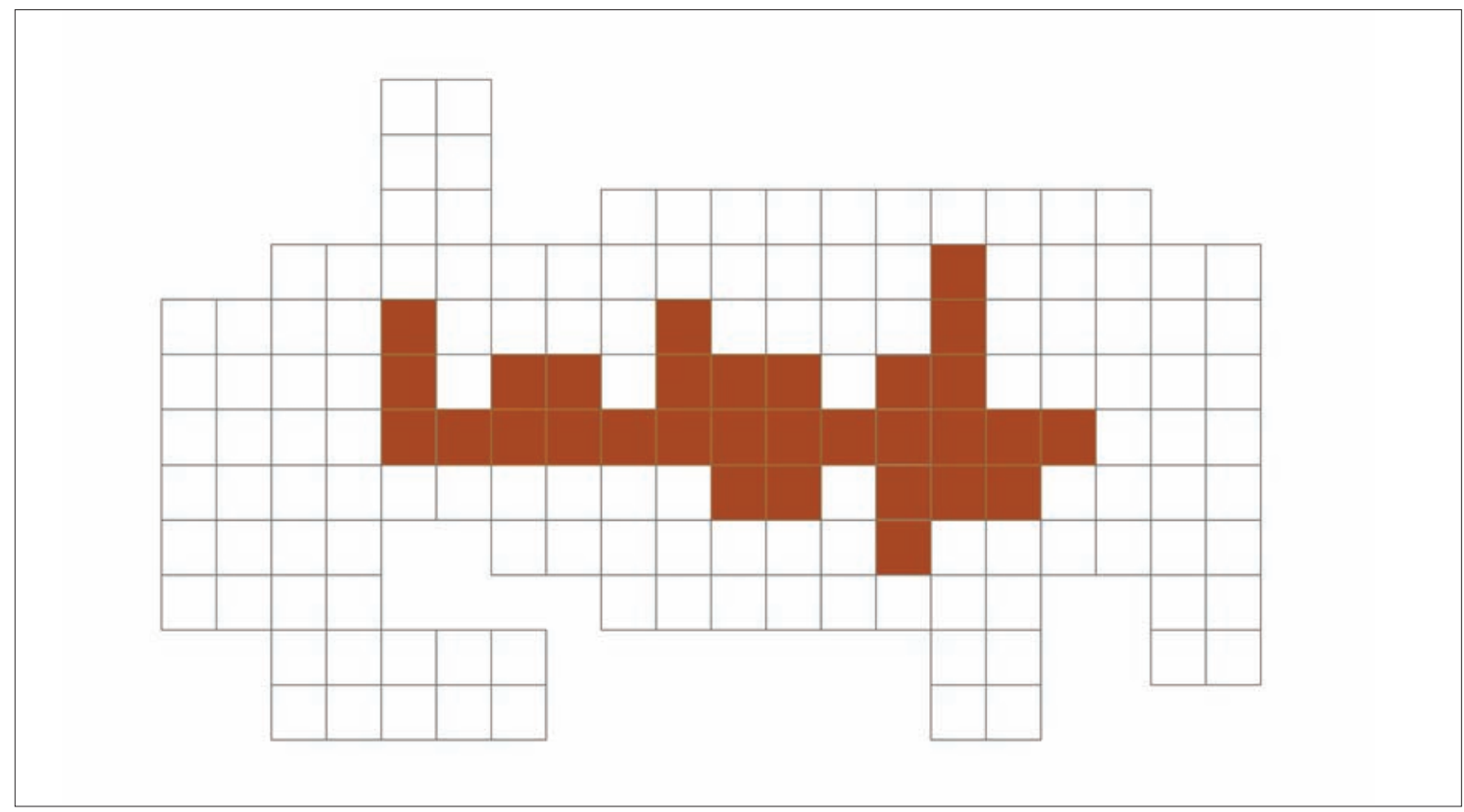

Fig. 4. The concentration of amber finds in the Daktariške 5 settlement (compiled by A. Butrimas).

bers from one to ten, depending on the length of the trench, while the width of the trench was marked ' $a$ ' and ' $b$ '. Trench III was marked with numbers from one to six. The discs were found in grid $4 \mathrm{~b}$ at a distance of 50 centimetres from each other, near the centre of the grid (Fig. 2). In the cross-section of the eastern part of trench III, we can see that the cultural layers in $4 \mathrm{~b}$ (2 $\mathrm{x} 2 \mathrm{~m}$ ) are as follows: the layer of arable soil was 30 to 35 centimetres thick; under the ploughed soil was a 35-to-45-centimetre layer of brown undispersed peat. Beneath this layer, starting at 65 to 80 centimetres deep, a cultural layer of waste peat started, with potsherds, pieces of animal bones, and amber ornaments. Beneath the cultural layer was soft lake clay. The cultural layer, like all the investigated area, sloped downwards in a southerly direction (about 30 centimetres in two metres). Two very well-preserved amber discs were found directly in the lower part of this cultural layer 85 to 87 centimetres from the ground surface, close to the untouched layer of soft lake clay.

According to the concentration scheme of amber finds in the Daktariškè 5 settlement, most amber ornaments, raw material and production waste were found at the centre of the settlement, where amber production probably took place. We collected 132 amber artefacts, test pieces, pieces of raw amber and production waste in the cultural layer of the Daktariške 5 settlement: 34 pendants and fragments, 18 button-shaped beads and pieces with a ' $\mathrm{V}$ ' shape perforation, five discs, of which one is unique, decorated with a cross and small triangles, two cylindrical and two simple beads, one ring (link), and one double button-shaped bead (Fig.
3 ). The amount of amber finds in the cultural layer, especially the quantity of raw material and production waste, which consists of 51 pieces, and its relation to the finished artefacts, does not allow us to assume that the objects produced here were produced in connection with a significantly large amber trade (Fig. 4). We can only assert that the amber artefacts were produced on the site to meet local needs, and that the spread of artefact production waste in the cultural layers takes up an area of only about 100 square metres, which is less than a sixth of the total settlement area.

\section{A description of the disc}

The decorated Daktariške 5 disc is 3.6 centimetres in diameter, and has a lens-shaped cross-section with a small hole at the centre; it has a fine polished surface, and is made of good-quality yellowish amber (Figs. 5, 6). One side of the artefact is divided into four unequal parts by a triple cross made of slight indentations. Along the edges, there are one, two and four small triangles in each of the four parts, in single and double broken lines of indentations. It appears that the remains of dark resin can still be seen in some of these indentations. Otto Tischler's research showed that these indentations were varied so that they might be filled with resin to add lustre to the object; this was done to a small number of artefacts. There was one small triangle with two lines of indentations in the smallest section marked out by a cross. In the next section clockwise from this quarter, two triangles were formed by a double line of indentations. In the next quarter there are

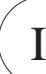

STONE AGE IN NORTHERN EUROPE: CHANGES IN LANDSCAPE, TECHNOLOGIES AND BELIEFS 


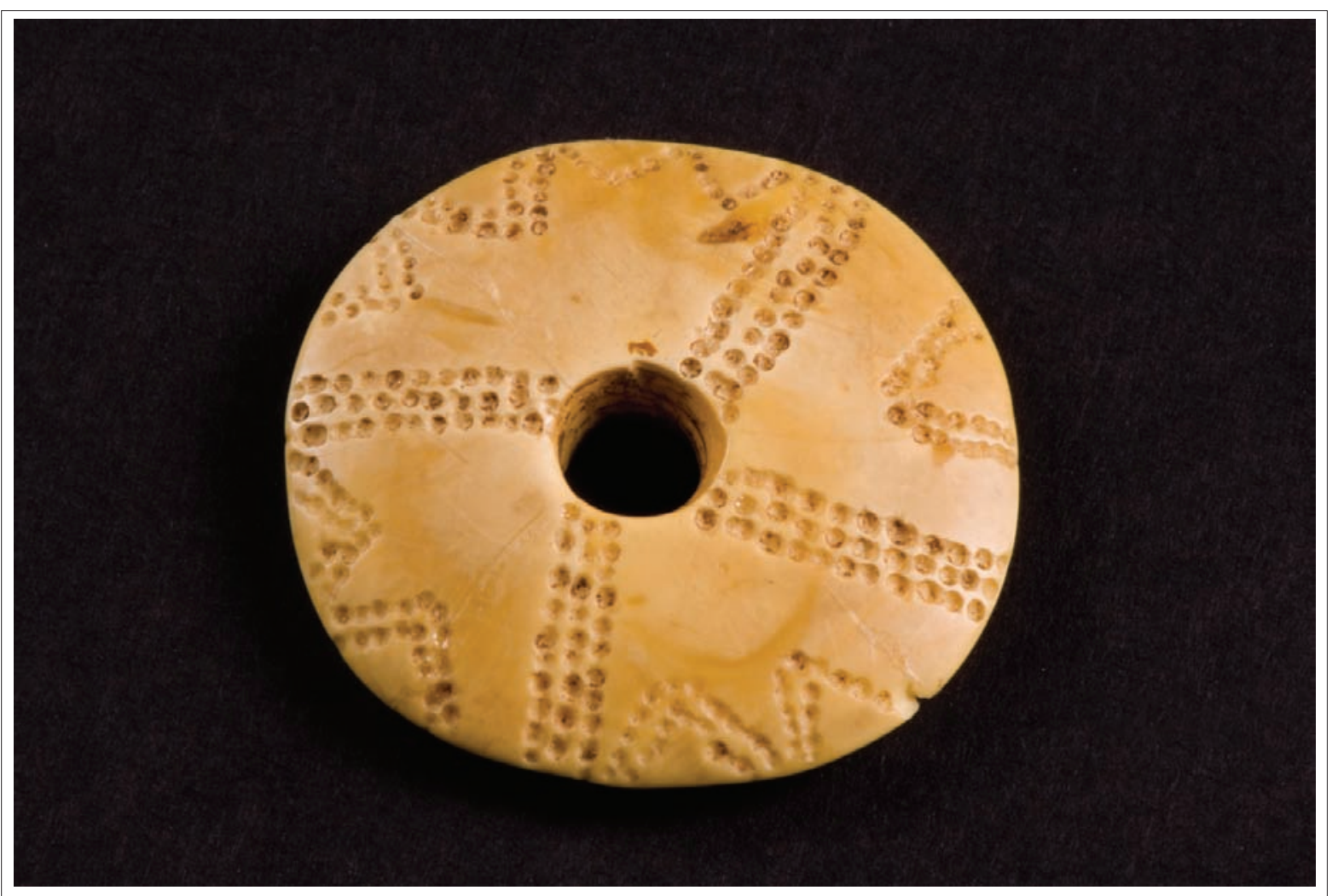

Fig. 5. The amber disc from Daktariške 5 (3.6 centimetres wide) (obverse). One side of the disc is divided into four unequal parts by a triple cross made of slight indentations. Along the edges one, two and four small triangles are formed in each of the four parts, in single or double broken lines (photograph by J. Butrimaite).

two more triangles. In the last and largest quarter (in a clockwise direction), there are four small triangles, two of which have a double and two a single line of indentations. Thanks to this composition, the triangles in each of the four quarters contain a different number of lines and indentations, which increases as the gaze moves clockwise. The smallest number of indentations in a quarter's triangles is 25 , the largest is 50 , while the middle quarters contain 37 and 38 indentations respectively. The decoration on this side of the disc is set out according to a principle of turning symmetry. The cross contains 125 indentations (Fig. 6). We cannot tell whether this system of calculation was formed for ornamental reasons, or for some symbolic, calendar or other reason; but it would be interesting to develop some hypotheses.

The other side of this disc is also interesting: along its edges are eight different-sized small triangles, formed by slight thin lines rather than by indentations. Alas, the different number of inscribed lines on the triangles does not have any obvious symmetry. To interpret these triangles, we might look at a contemporary festive cup from Nida, where we find on one side what is probably the oldest artistic motif not only in Lithuania but also in the whole of the southern and eastern
Baltic region. On the other side there is another motif: beneath four horizontal celestial lines there are triangles in six or seven striated bands. This decoration is common in even earlier European agricultural cultures, such as Funnel Beaker culture and Linear Band Ware culture. We may surmise that this is a symbol of agricultural fields (Rimantienè 1996, p. 294).

If an amber craftsman were asked to create a system of symbols that would fit into the four quadrants of a cross, it would be no easy task. We note that all four parts of the disc are unequal; the cross which divides it is not completely regular, as is often the case with discs decorated solely with a cross, or a cross surrounded by two lines of dots at the edges, which is what we find on the one from Būtinge site 2. Approximately 250 dots have been counted on this disc (Rimantienè 2005, pp. 486-487, Fig. 385: 2). Again, this number is divisible by 25 (Fig. 7). The local community may have given the craftsman who created the decorated disc from Daktariške the task of representing a system of symbols with which they were familiar. This is no easy task, because the composition comprises of a cross made of triple lines and double and single zigzag lines in which the number of hollows in each of the parts may have signified the number required for the community to 


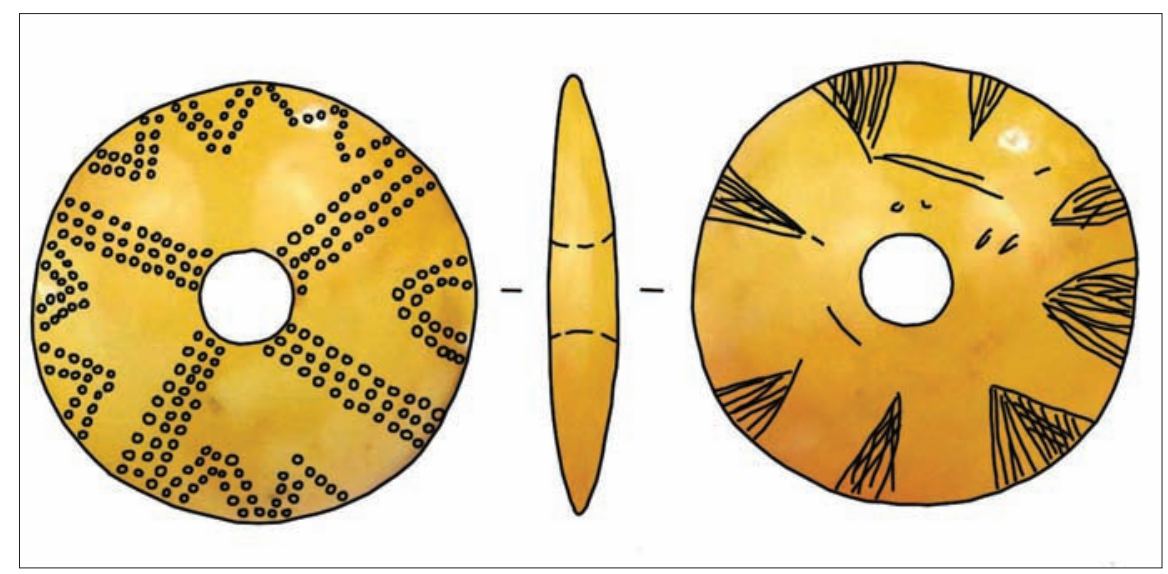

Fig. 6. The amber disk from Daktariškè 5 (obverse and reverse) (drawing by R. Spelskytè).

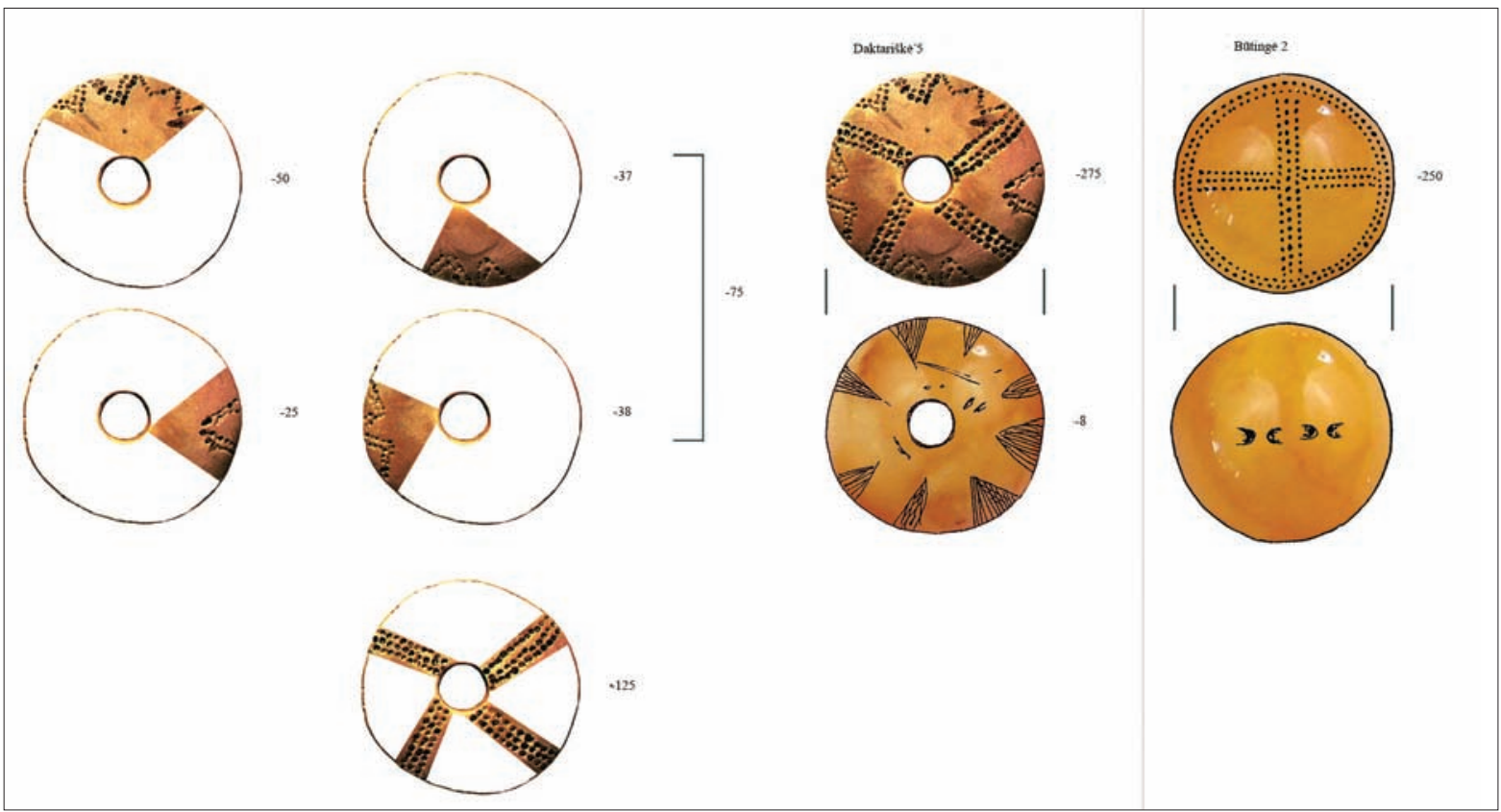

I

STONE AGE IN NORTHERN EUROPE: CHANGES IN LANDSCAPE, TECHNOLOGIES AND BELIEFS

Fig. 7. The system of decoration of discs from the Daktariške 5 and Būtingè 2 Neolithic settlements (drawing by R. Spelskytè).

construct its own disc symbolism. Clearly, it was necessary first to create the required number of zigzag lines with their component hollows, and then make the triple-lined cross, which could no longer be regular, and so the number of lines and hollows is different in each of the four quadrants. The whole task was made even more difficult for the Neolithic artist because all this complex system of counted hollows had to be fitted into a very small space (the diameter of the disc is 3.6 centimetres), and some of the area of the disc was lost by the hole bored into its centre. It remains only to marvel at the craftsman's skill, and there can be no doubt that his calculation skills were also excellent. This extends even further our appreciation of the intellectual capacity of the craftsman in particular, and the Neolithic communities that dwelt on the shores of Lake Biržulis in general. It is difficult to tell what sort of calculating system is marked by this decoration, or what symbolic, calendar, ritual or other significance it may have held. Perhaps we should begin our search for its meaning from the epoch in which it was created. First of all, this was a time of transition from hunting, fishing and gathering, in Central Europe and the continental forest zone, to agriculture and animal husbandry.

We found a few more discs in the Daktariškè 5 settlement. One of them has the same size of cross-section (a diameter of 3.4 centimetres). Three almost identical discs have been found at Juodkrantè (Klebs 1882 , 
Tafel I: 18, 19, 21). Their edges are decorated with small notches.

A massive, probably unfinished, disc, 6.7 centimetres wide and 1.9 centimetres thick, was found at Daktariškė 5. This stands out by its size, and for having one carefully polished side and one untreated one. Its cross-section is lens-shaped too. The disc from F. Tyszkiewicz's Palanga amber jewellery collection is almost identical to this artefact, although its width is slightly smaller (Rimantienè 2005, p. 216, Fig. 82: 10).

Only one amber ring was found at Daktariškè 5. This is an example of particularly fine jewellery craftsmanship, and is made from good-quality yellowish, slightly 'cloudy' amber with a carefully polished surface on all sides. The sides of the piece close to the edges are decorated with diagonal, shallow lines, which seem to become engraved as the object is turned. The very outer edge of the ring is decorated with much deeper and denser notches. These are known not only from Narva culture but also from Late Neolithic Globular-Amphora and Baltic Coastal cultures. They are also a frequent find in the area around Lake Luban in eastern Latvia, but there the cross-section is often more quadrangular (Loze 1979, Table LIX: 1, 2). These rings, which date from the Late Neolithic period, may have been influenced by the forms of schist rings.

As we have already said, amber discs are known from Lithuanian and Latvian sites from Early, and Middle Neolithic settlements and cemeteries, but the disc found at Daktariške 5 belongs to a special group of artefacts, called discs with cruciform decoration. These discs represent a completely different idea, and differ from those we have described in chronology, the circumstances in which they were discovered, and their areas, and they belong to a completely different cultural circle. Now we shall try to analyse these discs as a separate find group.

Typology, distribution and chronology of cruciform-decorated discs

We have managed to catalogue 37 amber discs decorated with a cross, with or without a small central drilled hole, of lens-shaped cross-section. They vary very much in size, from 2.5 to ten or 11 centimetres wide. They are made from amber of various colours. And they vary very much in their survival quality, from very poor survivals in Zlota and Globular-Amphora culture graves to very well-preserved items from wetland sites. The quality of their preservation makes it very hard to distinguish typology and interpret their symbolic meaning.
We have divided all known surviving cruciform-decorated amber discs into four typological groups:

1. Discs decorated only with a cross. The cross is usually composed of double or triple lines of dots or hollows, although some have been found with single lines of decoration. Twelve such discs have been found, and they are quite a numerous part of the cruciform-decorated discs (Fig. 8).

2. Discs whose cruciform decoration is in the centre of the disc, and the edges have a perimeter of one, two or three lines of dots or hollows. Thirteen of these have been found, and they form the largest group (Fig. 9).

3. Discs with a double or triple cross, and along the whole perimeter of the disc the edges have small single or double triangles (zigzag lines) formed from dots or hollows. This is also called a zigzag line. Seven such objects have been found (Fig. 10).

4. A mixed collection, comprising a cross made of incisions, discs decorated on one side, discs decorated with crosses with irregular, crooked lines, and unfinished items.

\section{Distribution}

After the cruciform-decorated discs were mapped, their geographical spread became clearer. We see two zones where the discs are concentrated. Most, almost half, are spread along the Baltic coast, in what is now Lithuania and Poland, in effect where Bay Coast (Rzucewo) culture thrived, from the settlements at Būtingè and Šventoji in the northeast to Słupsk in northern Poland. They cover mostly the shores of the Curonian Lagoon and the Vistula Lagoon, the area where Bay Coast and Globular-Amphora cultures thrived (Fig. 11) (Kilian 1955; Rimantienè 2005, pp. 123-205). According to Lothar Kilian, this was where Balt culture formed.

The most compact concentration of these discs is in the Mazurian Lakeland in northeast Poland, where discs of all types have been found. This is the Pomorze-Prussian or Mazurian-Prussian Group of Globular-Amphora culture (La Baume 1943; Wislanski 1966; Kempisty 1971; Okulicz 1973).

There is a very clear north and northeast boundary to the spread of cruciform-decoration discs in western Lithuania, with its northernmost outpost in the Būtinge 2 site, and the northeast boundary is marked by the Daktariške 5 settlement in the area around Lake Biržulis. The idea of making amber discs decorated with a cross did not spread further north, and none are found in what is now Latvia. They are not even found in the Sarnate settlement, which is territorially close 


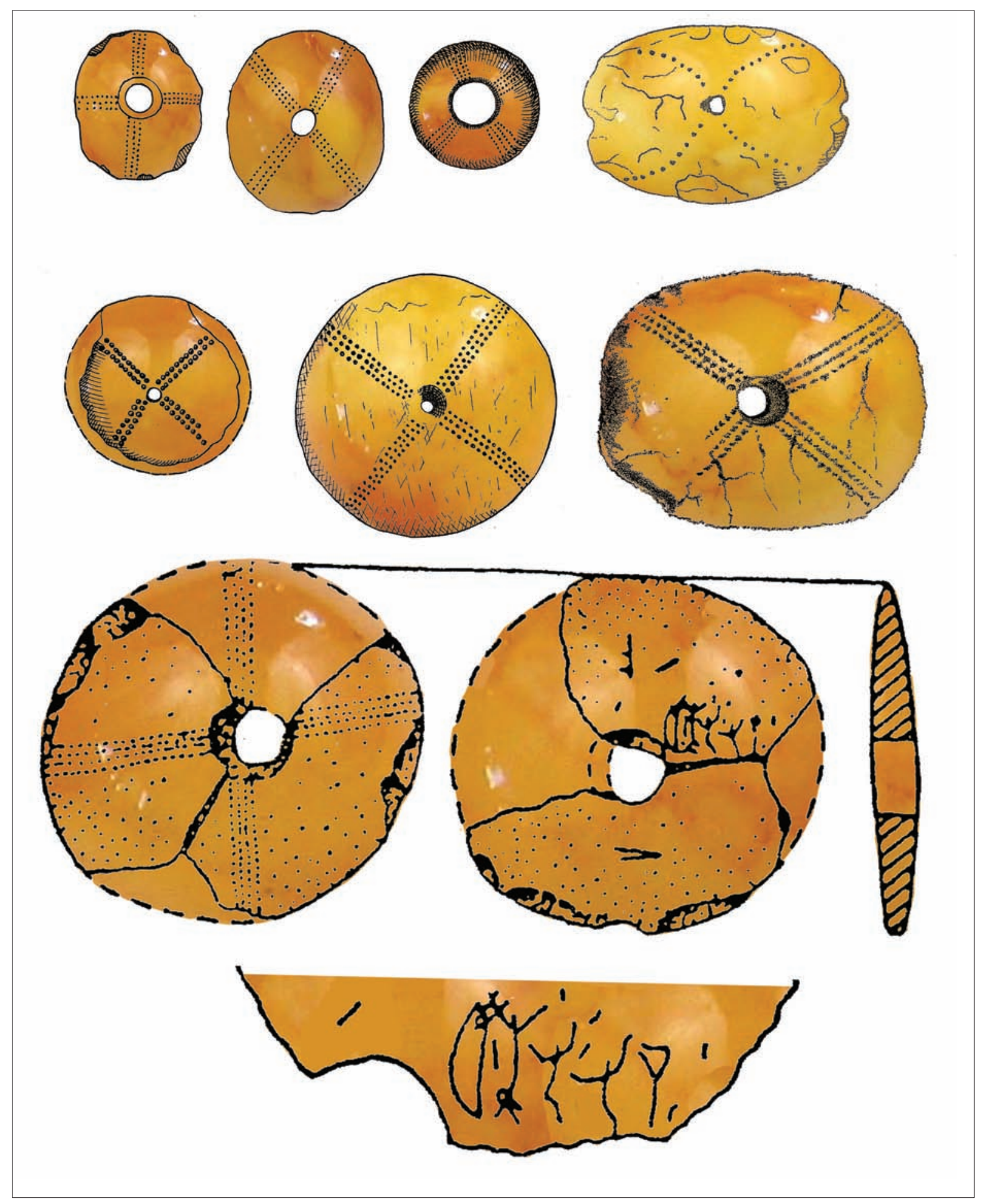

记

\section{I}

STONE AGE

IN NORTHERN

EUROPE:

CHANGES IN

LANDSCAPE,

TECHNOLOGIES

AND BELIEFS

Fig. 8. Group 1: amber discs decorated only with cross decoration (drawing by R. Spelskyte). 


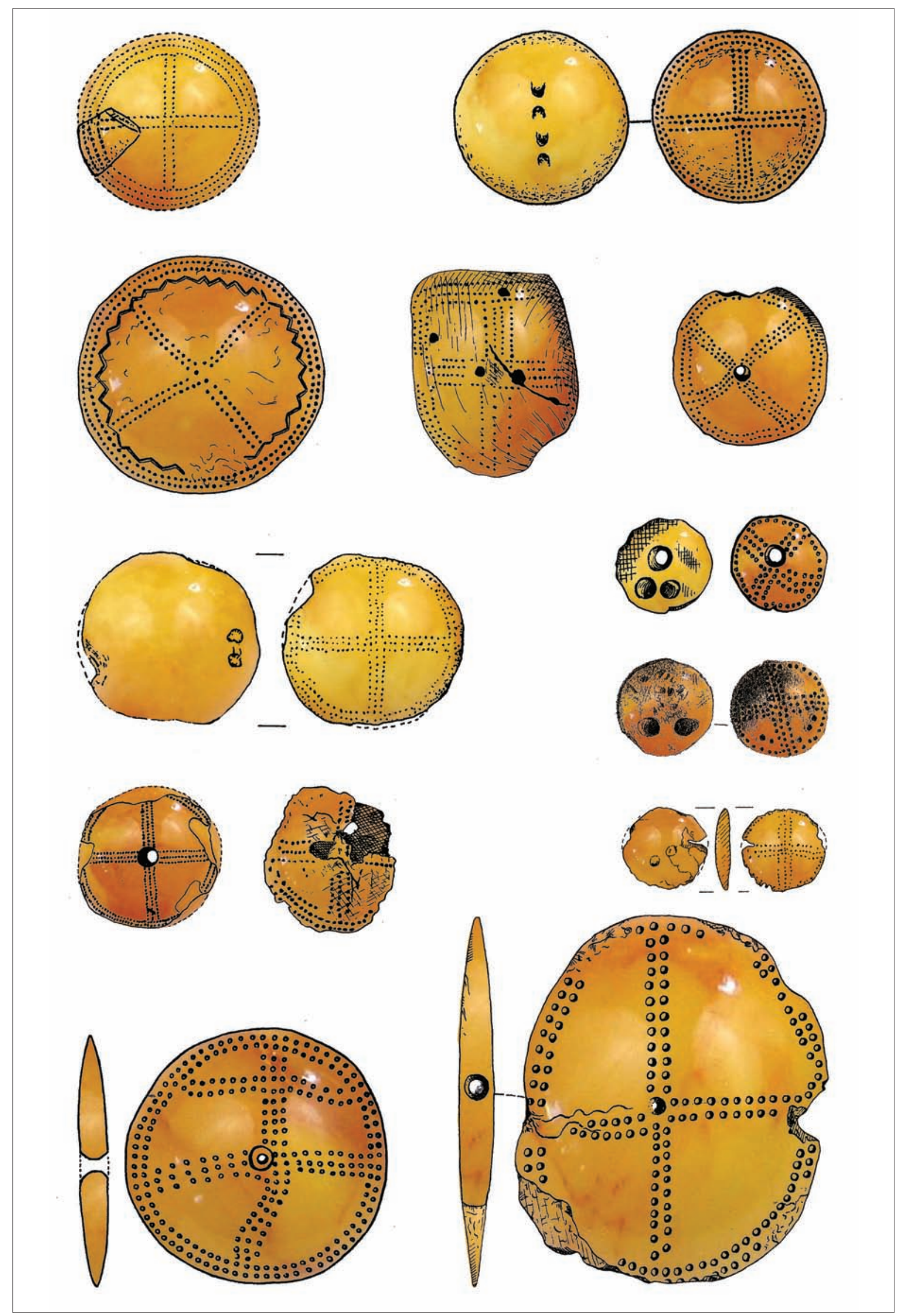

Fig. 9. Group 2: amber discs with cruciform decoration in the centre and a ring of indentations on the edges (drawing by R. Spelskytė). 


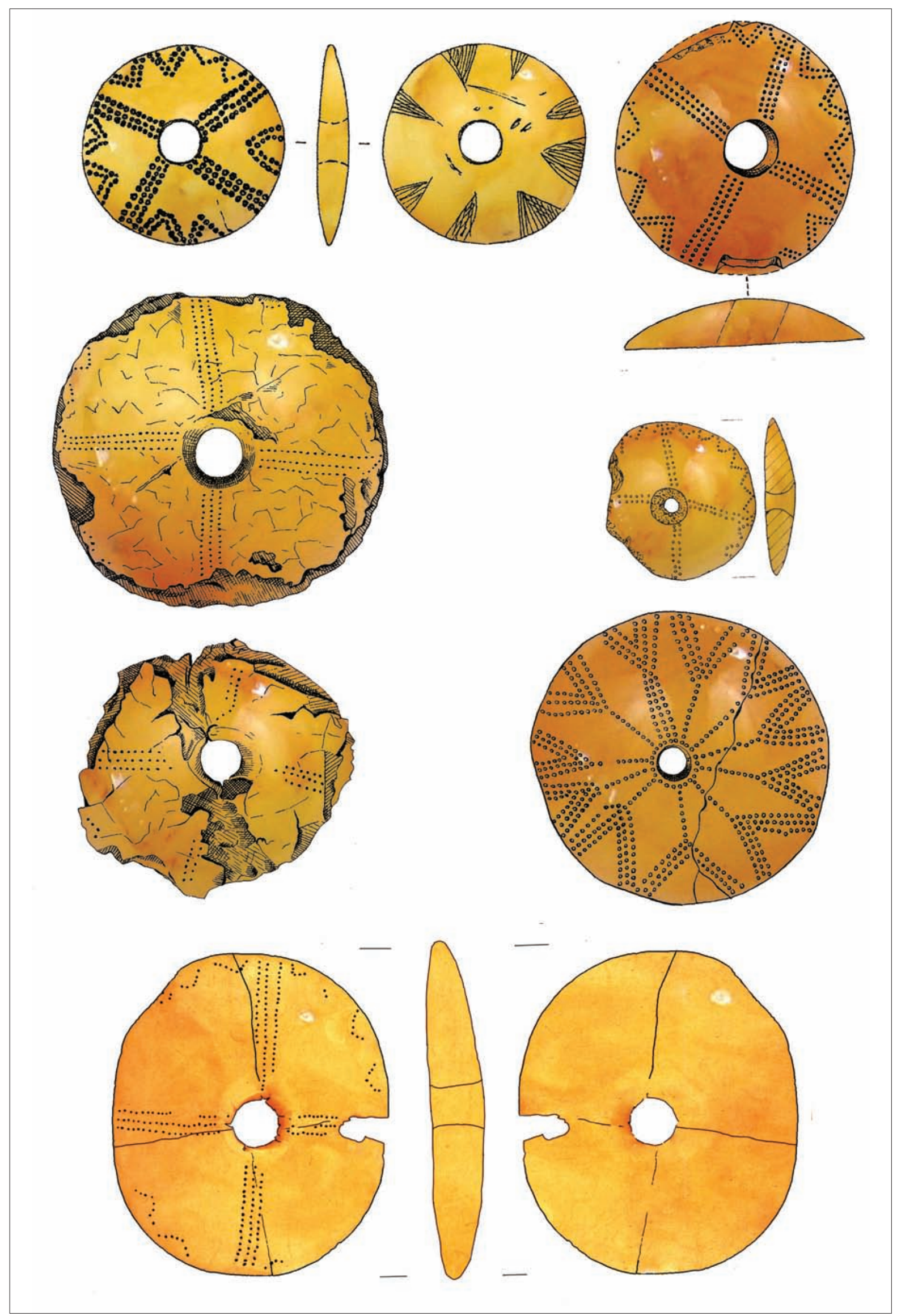

\section{I}

STONE AGE

IN NORTHERN

EUROPE:

CHANGES IN

LANDSCAPE,

TECHNOLOGIES

AND BELIEFS

Fig. 10. Group 3: amber discs with a cross and edges with triangular zig-zag lines (drawing by R. Spelskytè). 


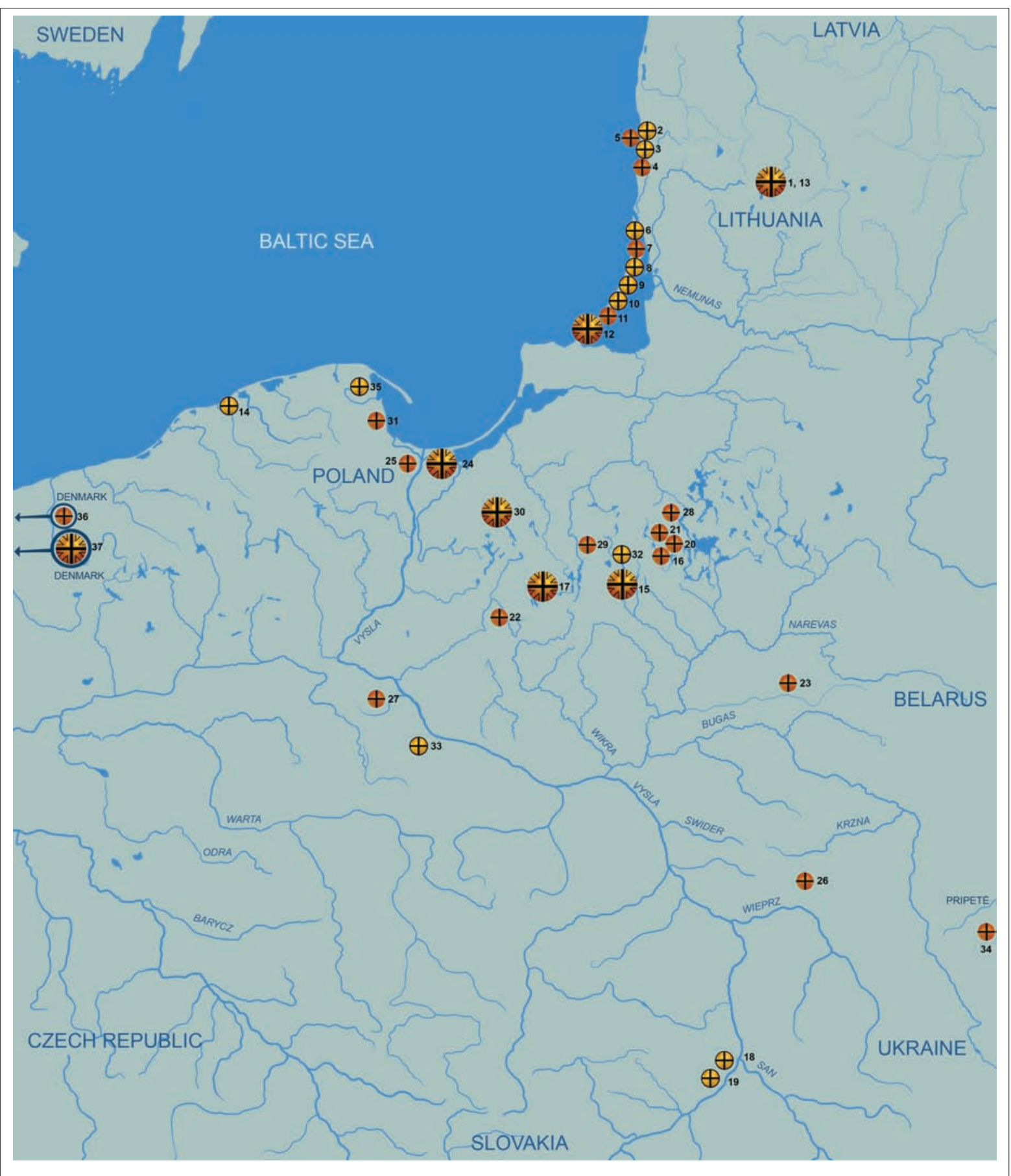

Fig. 11. A map of the spread of amber disc cross decoration: 1 discs with a double or triple cross, and the edges have small single or double triangles formed from dots or hollows along the whole perimeter of the disc; 2 discs with a double or triple cross, and indentation in the form of a ring along the whole perimeter of the disc; 3 discs decorated only with a cross. Lithuania, Poland, western Ukraine (compiled by R. Spelskytė). 
to Būtinge, and is rich in amber artefacts. Nor are they known in the amber artefact collections from the lowlands around Lake Luban. The boundary of their distribution stretches as far as places influenced by the ideas of Globular-Amphora and Bay Coast cultures.

The southern boundary of their distribution is southern Poland and northwest Ukraine, where Globular-Amphora and Zlota cultures thrived (Szmyt 1999; Svieshnykov 1983; Krzak 1976).

\section{Find circumstances}

Most of these discs were found in settlements of Bay Coast or Globular-Amphora cultures on the Lithuanian and Polish coast, and along the shores of the Curonian Lagoon and the Vistula Lagoon. They are known as accidental finds, found on occasion in hoards or in Globular-Amphora and Zlota culture graves, mostly in the Mazurian Lakeland or along the banks of rivers in the Vistula basin. The quality of their state of preservation differs: finds from Dakatriškè 5, Būtingè, Šventoji, the Palanga hoard and some from Juodkrante are particularly well preserved. These are all connected in one way or another with wetland sites, or lay deep underwater. Unfortunately, all the discs that were found in graves in what is now Poland are more or less fragmented, with flaked or decayed edges, a cracked surface, or a decaying patina; sometimes their finders 'polished' the surface. This does not allow us to recreate all of their decorative system with complete accuracy, and hence we have considerably less chance of 'reading' them. In this context, the items found in the settlements at Daktariškè 5 and Būtingè 2 have a particular significance in interpreting the sybolism encoded on these discs.

Since a large part of the Globular-Amphora culture graves containing discs were excavated in the 19th or early-20th centuries, and were not carbon-dated but dated generally, quite exact dates for Globular-Amphora culture in Poland have been established in the period between 3300 and 2200 cal BC. The date of the disc and the unfinished disc found at the Daktariške 5 settlement is 3096-2885 cal BC, the dates of the cultural layer with the disc at Šventoji settlement 1 are 2880-2495 and 2882-2582 cal BC, and the date of Šventoji settlement 23 is between 2880-2623 and 2271-1984 cal BC. Thus, most discs decorated with a cross from Lithuania could be dated to between 3100 and $2500 \mathrm{cal} \mathrm{BC}$, and attributed to Globular-Amphora and Bay Coast culture sites. We have no radiocarbon dating for the excavated Zlota culture cemetery with discs, but these sites have been dated by Z. Krzak, who has studied them, to a period between 2800 and 2200 cal BC.

Thus, the common period for amber discs with cruciform decoration found in all cultures extends for more than a thousand years, between 3300 and 2000 cal BC.

\section{FTIR and micro FT-Raman spectral analysis}

FTIR and micro FT-Raman spectral analyses were carried out in the National Museum of Lithuania and State Research Institute Centre for Physical Sciences and Technology in Vilnius.

For a long time, IR spectral analysis was a common technique for the numerous investigations of natural resin, gum, pitch and tar, as well as amber artefacts in art and archaeological objects (Font et al. 2007; Shillito et al. 2009; Lettieri 2015; Sathya, Velraj 2011; Venkatachalapathy 2003). In recent years, the more modern method of Raman spectroscopy has appeared to be a powerful tool for investigating material at a molecular level, because it does not damage. Although fossilised resin (amber) has been investigated quite widely (Edwards, Farwell 1996; Edwards et al. 2007; Brody et al. 2001; Vandenabeele et al. 2003; Vandenabeele et al. 2000), the examination of residues on the surface was not so extensive. Thus, FTIR and Raman spectral analysis of the brown residues in pits (Fig. 12) and the red remnants in scratches on the other side of an amber disc (Fig. 13) was carried out to obtain more information.

\section{FTIR spectroscopy}

FTIR analysis was performed using a spectrophotometer FTIR - 8400S, SHIMADZU with attached IR microscope AIM - 8800, SHIMADZU. Samples were pressed in a diamond cell Thermo Spectra-Tech $\mathrm{P} / \mathrm{N}$ 0045-344, scan number 200, resolution $4(1 / \mathrm{cm})$.

\section{Raman spectroscopy}

Raman measurements were performed with $785 \mathrm{~nm}$ (diode laser) excitation by using a Renishaw in Via Raman microscope, equipped with grating containing 1200 groove/mm. Laser power was $1.1 \mathrm{~mW}$. A Raman spectrum was taken using a $20 \times$ lens. Integration time was 100 s.

The IR and Raman spectra were analysed using Gams/ AI 8.0 software (Thermo Scientific Corp.).

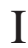

STONE AGE IN NORTHERN EUROPE: CHANGES IN LANDSCAPE, TECHNOLOGIES AND BELIEFS 


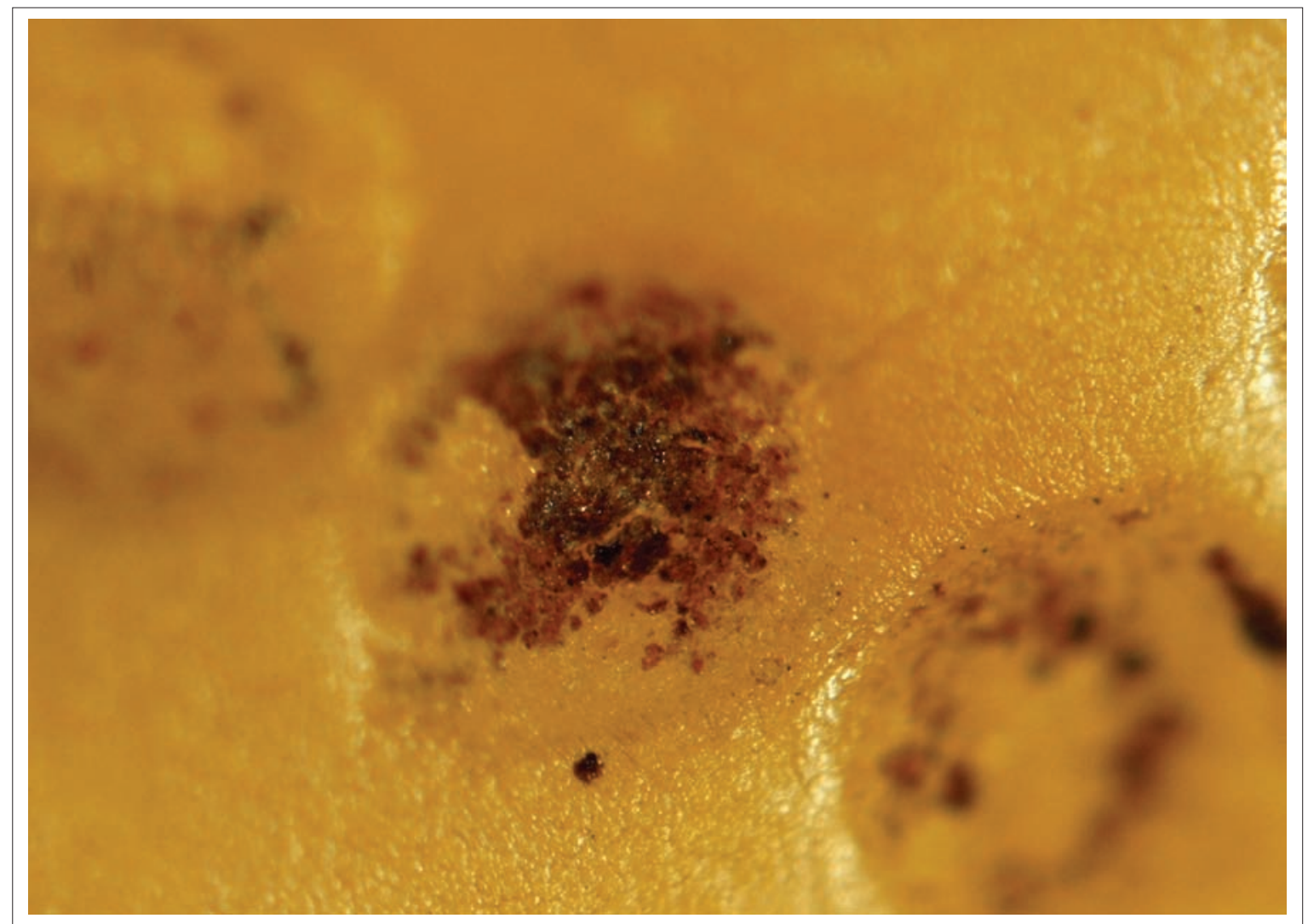

Fig. 12. Brown remnants in a pit, amber disc, EM 22452804, microphotograph, x 63 (photograph by R. Ulozaitè).

\section{Results}

The brown substance in the pits was investigated by FTIR spectroscopy. A mixture of coniferous tree resin, and probably some gum, beeswax and fat, was identified. The broad band in high frequency region (Fig. 14, B) at $3340 \mathrm{~cm}^{-1}$ is assigned to $\mathrm{OH}$ group, characteristic to hydrogen bonding in polysaccharides and other organic molecules capable to forming them. Bands at 2962, 2925 and $2850 \mathrm{~cm}^{-1}$ are specific for hydrocarbon chain (Font et al. 2007; Shillito et al. 2009; Lettieri 2015; Sathya, Velraj 2011; Venkatachalapathy 2003; Socrates 2001). Vibrational bands at 1711 and $1664 \mathrm{~cm}^{-1}$ belong to carbonyl group, thus 1451 and $1413 \mathrm{~cm}^{-1}$ are scissoring vibration of $\mathrm{CH}_{2}$ in chain (Socrates 2001). Also, vibrational band at 1413 can be assigned to carbonate stretching, and together with band at $872 \mathrm{~cm}^{-1}$ shows the presence of carbonates (Shillito et al. 2009; Lettieri 2015). The broad band at $1052 \mathrm{~cm}^{-1}$ overlaps the vibrational modes of these functional groups $\mathrm{C}-\mathrm{O}, \mathrm{O}-\mathrm{Si}-\mathrm{O}$, Al-O-Si (Font et al. 2007; Shillito et al. 2009; Lettieri 2015; Sathya, Velraj 2011; Venkatachalapathy 2003). More assignments of vibrational bands are represented in Table 1. The brown substance in the pits was also investigated by Raman spectroscopy, but there was no useful data, the spectra showed only high florescence.
Spectral analysis of a light red material (Figs. 15, 16) showed slightly different results. Vibrational bands at $3695,3670,3650$ and $3620 \mathrm{~cm}^{-1}$ in high frequency region of IR spectrum (Fig. 15, B) are characteristic to free OH groups (Socrates 2001). It could be crystal water (few water molecules) or polymers, where $\mathrm{OH}$ groups cannot interact with each other. Vibrational bands characteristic of hydrocarbon chains at $2955,2918,2850 \mathrm{~cm}^{-1}$ in high frequency and 1473 , $1463,1377,730$ centimetres $^{-1}$ in 'fingerprint' spectral regions (Font et al. 2007; Shillito et al. 2009; Lettieri 2015; Sathya, Velraj 2011; Venkatachalapathy 2003; Socrates 2001) were also found. Carboxyl groups are observed at 1740 and $1713 \mathrm{~cm}^{-1}$ (Font et al. 2007; Shillito et al. 2009; Lettieri 2015; Sathya, Velraj 2011; Venkatachalapathy 2003; Socrates 2001). The weak band at $1540 \mathrm{~cm}^{-1}$ in IR spectrum (Fig. 15, A) is assigned to $v(\mathrm{CCH})$ ring for aromatic resins (Socrates 2001). It was also observed in Raman spectrum (Fig. 16, A) at 1529 centimetres $^{-1}$. IR spectrum of light red material also shows bands characteristic to clays. Unlike the brown substance, there are two bands at $940,914 \mathrm{~cm}^{-1}$ assigned to Al-OH deformation or Si-O bending vibrations (Font et al. 2007; Shillito et al. 2009; Lettieri 2015; Sathya, Velraj 2011; Venkatachalapathy 2003). Also, the new band is observed in the light red material 


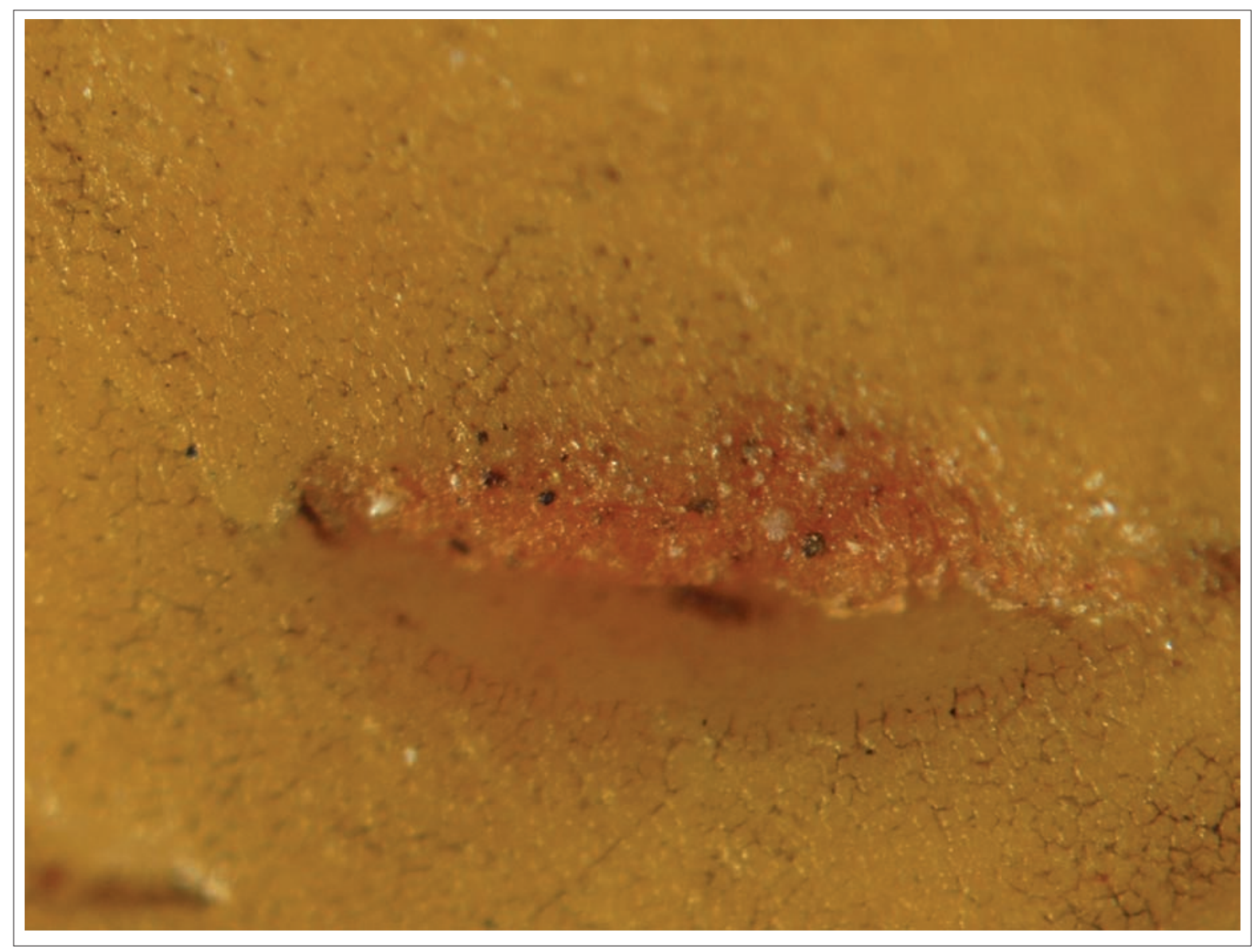

Fig. 13. Light red material, amber disc, EM 22452804, microphotograph, x 90 (photograph by R. Ulozaitè).

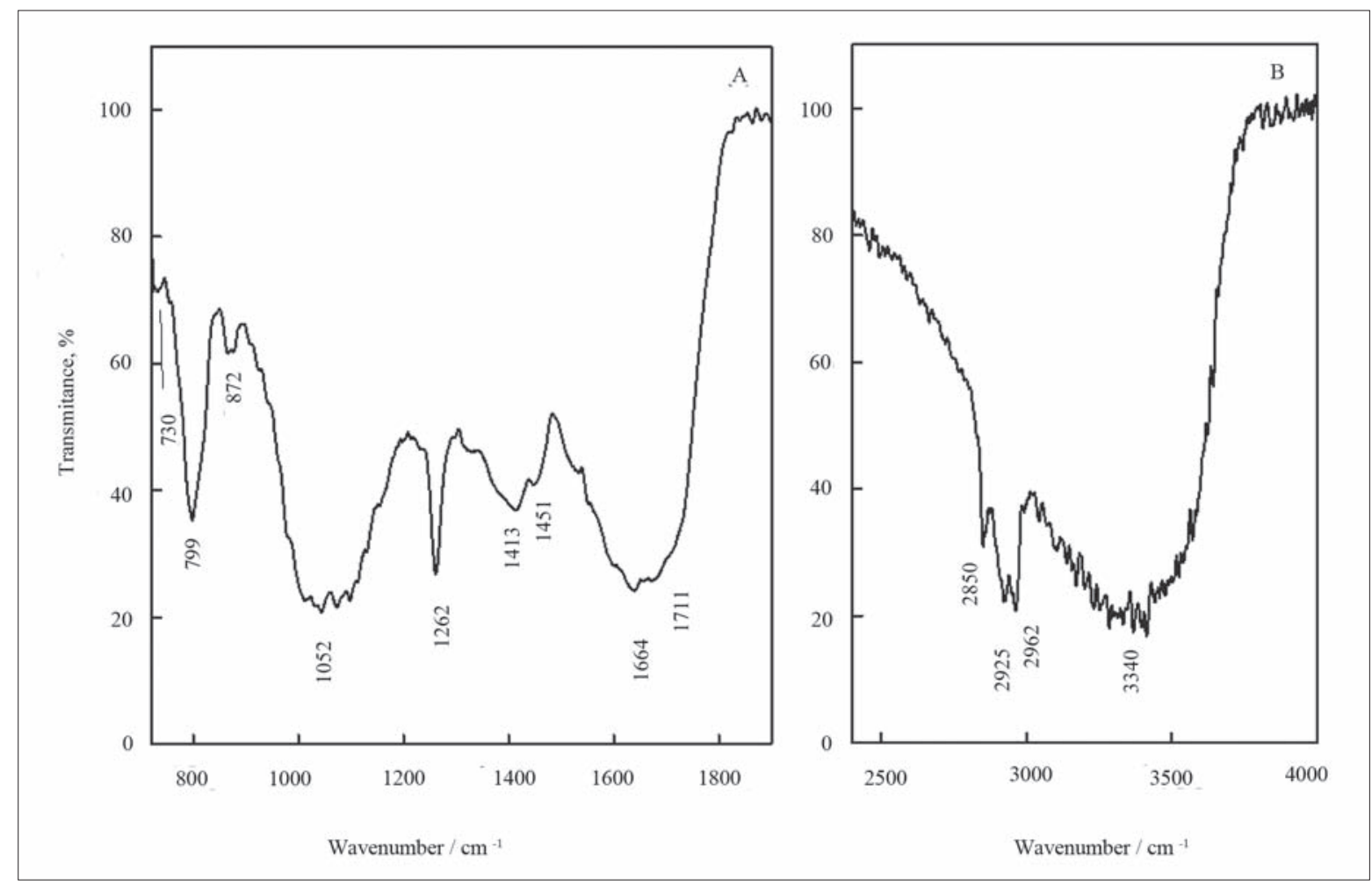

Fig. 14. IR spectrum of brown remnants, amber disc EM 22452804, 'Fingerprint' (A) and high frequency spectral region (B) (compiled by R. Ulozaitè). 


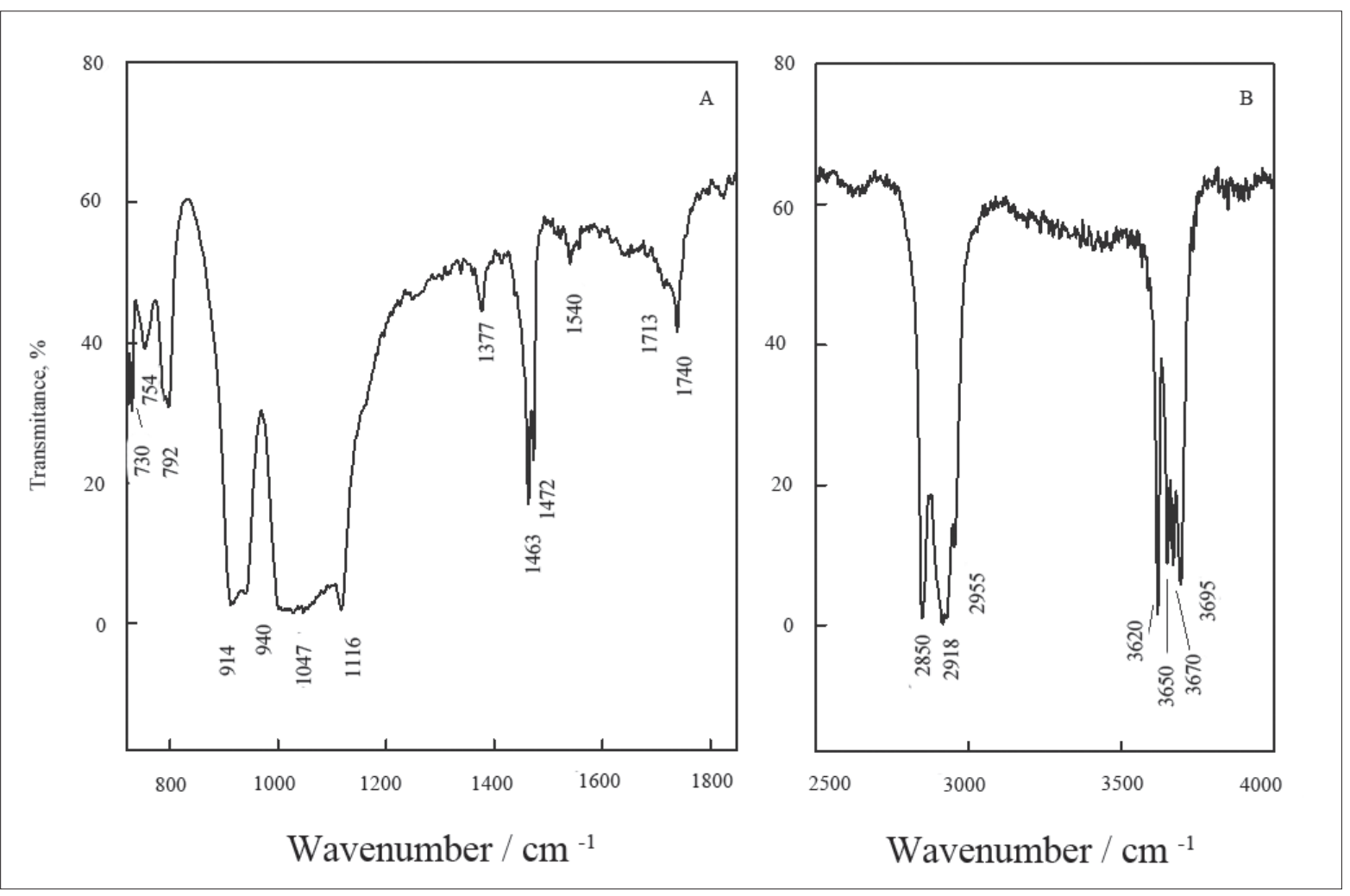

Fig. 15. IR spectrum of light red residues (scratches), amber disc, EM 22452804 (compiled by R. Ulozaitè).

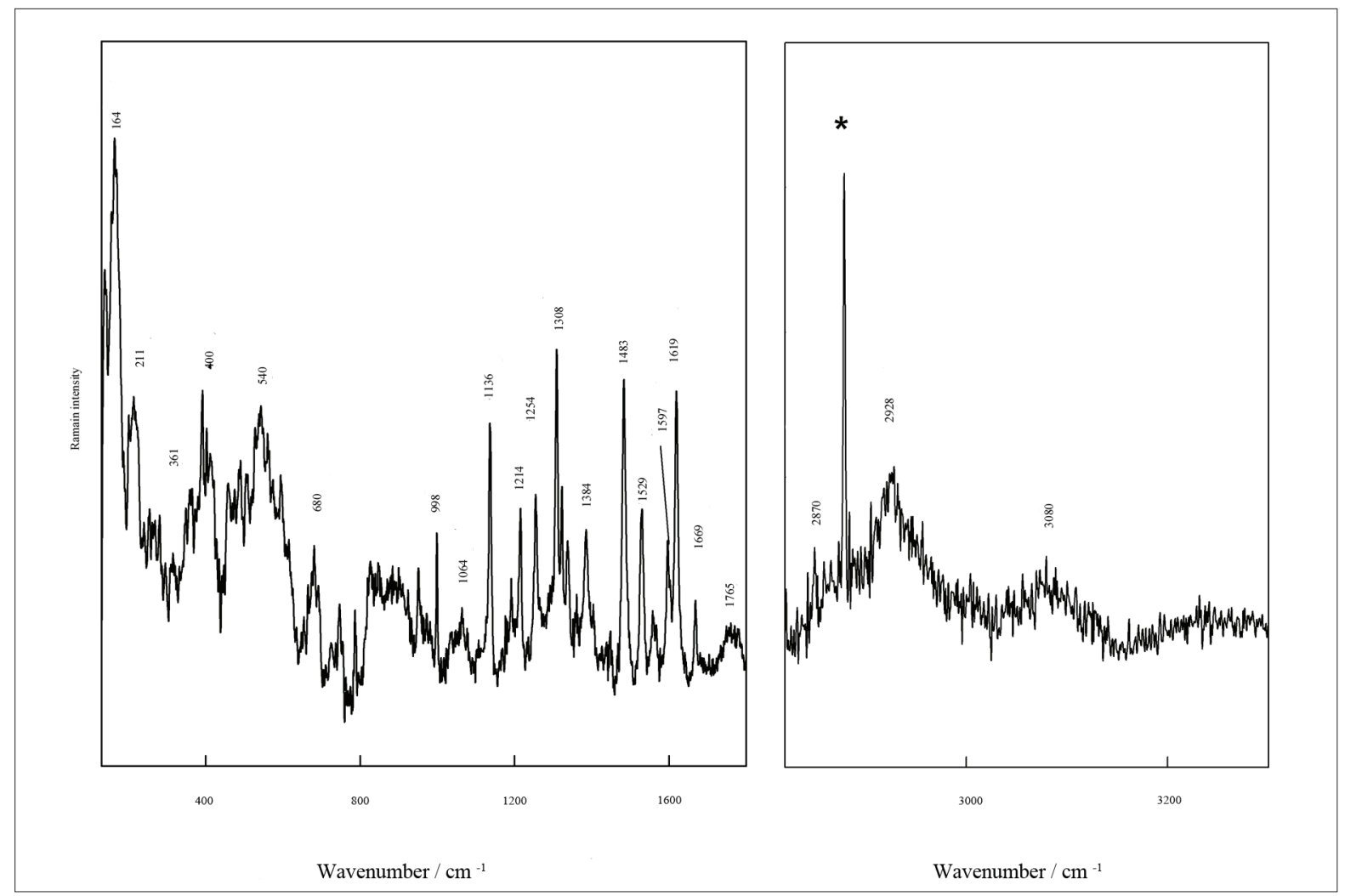

Fig. 16. Raman spectra of a red defect in amber, amber disc EM 22452804, 'Fingerprint' (A) and high frequency spectral region (B) (compiled by I. Matulaitienè). 
Table 1. Assignments of vibration modes in amber

\begin{tabular}{|c|c|c|c|}
\hline \multicolumn{3}{|c|}{ Frequency centimetres $^{-1}$} & \multirow[t]{2}{*}{ Approximate assignments of vibrational } \\
\hline \multirow[b]{2}{*}{ FTIR $^{b}$} & \multirow[b]{2}{*}{ FTIR $^{r}$} & \multirow[b]{2}{*}{$\operatorname{Raman}^{\mathrm{r}}$} & \\
\hline & & & \\
\hline \multirow[t]{4}{*}{-} & 3695 & - & $\mathrm{OH}$, crystal water; polymeric $\mathrm{O}-\mathrm{H}$ (there is no \\
\hline & 3670 & & interaction between $\mathrm{O}-\mathrm{H}$ groups) \\
\hline & 3650 & & \\
\hline & 3620 & & \\
\hline 3340 & - & - & $v(\mathrm{OH})$ stretching, hydrogen-bonded \\
\hline- & - & 3080 & $v(\mathrm{CH}), \mathrm{C}=\mathrm{CH}_{2}$ aromatic ring \\
\hline 2962 & 2955 & - & $v_{93}\left(\mathrm{CH}_{3}\right)$ aliphatic \\
\hline 2925 & 2918 & 2928 & $v_{\mathrm{as}}\left(\mathrm{CH}_{2}\right), v_{\mathrm{s}}\left(\mathrm{CH}_{3}\right)$ \\
\hline 2850 & 2850 & 2870 & $v_{s}\left(\mathrm{CH}_{2}\right), v_{\mathrm{s}}\left(\mathrm{CH}_{3}\right)$ \\
\hline- & - & 1765 & $v(\mathrm{C}=\mathrm{O})$ \\
\hline- & 1740 & - & $v(\mathrm{C}=\mathrm{O})$ \\
\hline 1711 & 1713 & - & $v(\mathrm{C}=\mathrm{O})$ \\
\hline 1664 & - & 1669 & $v(\mathrm{C}=\mathrm{O})$ \\
\hline- & - & 1619 & $v(\mathrm{C}=\mathrm{C})$ conjugated unsaturated \\
\hline- & 1540 & 1529 & $v(\mathrm{CCH})$ ring for aromatic resins \\
\hline- & 1473 & 1483 & $\delta\left(\mathrm{CH}_{2}\right)$ \\
\hline 1451 & 1463 & - & $\delta\left(\mathrm{CH}_{2}\right)$ \\
\hline 1413 & - & - & $\delta\left(\mathrm{CH}_{2}\right)$ \\
\hline- & 1377 & 1384 & $\delta\left(\mathrm{CH}_{2}, \mathrm{CH}_{3}\right)$ \\
\hline- & - & 1308 & $\delta\left(\mathrm{CH}_{2}, \mathrm{CH}_{3}\right)$ \\
\hline 1262 & - & 1254 & $\delta(\mathrm{CCH}), v(\mathrm{C}-\mathrm{O})$ \\
\hline- & - & 1214 & $\delta(\mathrm{CH})$ chain deformations, $v(\mathrm{CC})$ aliphatic \\
\hline- & 1116 & - & $v(\mathrm{C}-\mathrm{O}-\mathrm{C})$ esters or $v(\mathrm{Si}-\mathrm{O}-\mathrm{Si})$ \\
\hline- & - & 1136 & $v(\mathrm{CC})$ ring breathing \\
\hline- & - & 1064 & $v(\mathrm{CC})$ aliphatic \\
\hline 1052 & 1047 & - & $v(\mathrm{C}-\mathrm{O})$ \\
\hline- & - & 998 & $v(\mathrm{CC})$ aromatic \\
\hline- & 940 & - & $\delta(\mathrm{Al}-\mathrm{OH})$, Si-O bending \\
\hline- & 914 & - & $\delta(\mathrm{Al}-\mathrm{OH}), \mathrm{Si}-\mathrm{O}$ bending \\
\hline 872 & - & - & - \\
\hline 799 & 792 & - & Si-O bending \\
\hline- & 754 & - & Si-O bending \\
\hline- & - & 748 & (CC) isolated \\
\hline 730 & 730 & & $\delta\left(\mathrm{CH}_{2}\right)$ \\
\hline- & - & 680 & $v(\mathrm{CS})$ \\
\hline- & - & 540 & $\begin{array}{l}\mathrm{Si}-\mathrm{O}-\mathrm{Si} \text { bending or } \mathrm{SiO} \text { silicates, or } \delta(\mathrm{CCO}) \text { and } \\
\delta(\mathrm{COC}) \text { in plane }\end{array}$ \\
\hline- & - & 400 & $\delta(\mathrm{CCO}), \delta(\mathrm{Si}-\mathrm{O})$ \\
\hline- & - & 361 & $\delta(\mathrm{CCC})$ \\
\hline- & - & 211 & Si-O bending, O-H-O bending \\
\hline- & - & 164 & O-Al-O bending \\
\hline
\end{tabular}

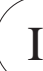

STONE AGE

IN NORTHERN

EUROPE:

CHANGES IN

LANDSCAPE,

TECHNOLOGIES

AND BELIEFS

b Brown remands; rlight red material. *Based on references [1-14]. Abbreviations: $v$ - stretching, $\delta$ - deformation.

IR spectrum at $1116 \mathrm{~cm}^{-1}$ which shows the presence of esters (v(C-O-C)) (Vandenabeele et al. 2000). This band also belongs to $v(\mathrm{Si}-\mathrm{O}-\mathrm{Si})$ vibration. Bands at 794 and $754 \mathrm{~cm}^{-1}$ are assigned to Si-O bending vibrations (Table 1).

For a better understanding, a light red defect was investigated by Raman spectroscopy. Raman spectra gave high florescence, but corresponded well with IR data (Table 1). The vibration modes in the high fre- quency region (Fig. 16) at 2928 and $2870 \mathrm{~cm}^{-1}$ are assigned to $\mathrm{CH}_{2}, \mathrm{CH}_{3}$ stretching (Edwards, Farwell 1996; Edwards et al. 2007; Brody et al. 2001; Vandenabeele et al. 2003; Vandenabeele et al. 2000; Socrates 2001), and are specific to organic compounds such as waxes or lipids. In the 'fingerprint' region, bands characteristic of a hydrocarbon chain are observed at 1483, 1384, 1308, 1214, $1064 \mathrm{~cm}^{-1}$ (assignments are presented in Table 1). Vibrational bands at 3080 centimetres $^{-1}$ in 
high frequencies and 1529, 1136, $998 \mathrm{~cm}^{-1}$ in the 'fingerprint' region (Edwards, Farwell 1996; Edwards et al. 2007; Socrates 2001) show the presence of aromatic. The low frequency bands at 164 and $211 \mathrm{~cm}^{-1}$ are assigned to O-Al-O and Si-O or O-H-O bending vibrations respectively (Frost et al. 1993; Frost 1995; Frost, Shurvell 1997). Bands at 540 and $400 \mathrm{~cm}^{-1}$ probably belong to $\mathrm{Si}-\mathrm{O}-\mathrm{Si}$ and $\delta(\mathrm{Si}-\mathrm{O})$.

This investigation has proven that FTIR and micro FT-Raman spectroscopy can be a particularly suitable technique for the analysis of important archaeological objects. The results obtained can be seen as evidence that decoration, such as pits and lines after engraving, was most likely highlighted by the application of resin mixture, whereas the reddish substance could be clay.

\section{Interpreting the symbolic meaning. Discs as prestige objects}

The fact that these artefacts were placed in graves allows us to suppose that they were ritual objects, and the fact that they were found decorated with various quite complex geometric systems suggests that they were connected with religion, and perhaps conceal some essential information which would allow us to understand the social organisation of Neolithic societies. In our analysis, we shall attempt to explain the regularity of their iconographic system, and establish with what calendar or ideological phenomena they might be associated.

The authors know of at least ten such discs found in Globular-Amphora cemeteries, in what is now Poland and Ukraine. The amber discs with cruciform decoration, like the amber rings also found in these graves, are usually single finds placed on the vertices of the dead, and these objects are usually not a component part of amber strings, and only sometimes were they accompanied in different graves by supplementary amber artefacts. This special way of wearing them is confirmed by the discs found in the Brześć Kujawski Globular-Amphora culture grave, which are made of bone and decorated with a cross design, and which were placed on ritually buried bull-head vertices, and, like the amber discs from group three, they had small punctured triangles around their edges. Thus, amber and bone discs almost identical in their decoration represented the same cult symbolism. The special place in the grave of these amber discs, the delicate nature of the amber, and the consuming amount of time and skill needed to create them, lead us to believe that they may have been worn only during ceremonies, and being placed in the grave reveals the amount of ritual symbolism they embodied. Those who have studied
Globular-Amphora culture graves have also noted that only central burials contained amber jewellery, while they were not found at all in any other graves, or such items were found only singly.

Krzak does not indicate where in the grave the amber discs were found in Zlota culture (Krzak 1976, pp. 144-145). Šturms drew attention to the special circumstances in which another disc with cruciform decoration was found at Groß Morino (now Murzynowo): it was found with a boat-axe and Early Corded Ware pottery. This would indicate that certain forms of disc were common to both Globular-Amphora culture and the early stages of Boat-Axe culture (Šturms 1956, p. 14; Kosko 1989, pp. 46-58). At the same time, this marks another interesting circumstance: both artefacts, the amber disc with cruciform decoration and the boat axe, are often interpreted as prestige objects. It is worth noting here that the amber disc with cruciform decoration from the Būtinge 2 settlement was also found with a carefully polished and completely unused boat-axe made of plagioclase porphyrite (Rimantienè 2005, p. 202).

Amber discs are found in male graves; they are usually found separately, even if more amber artefacts are found, as we have said, by the head in graves (Šturms 1956, p. 15).

Many researchers think that amber cross-decorated discs represent the sun (Šturms 1956, p. 15), and are connected with the cult of the sun, and that gold-shining amber found in the southeast Baltic coastlands was a suitable material to express this symbol. When we recall that back in the 19th century O. Tischler established that this symbolic artefact was further embellished by pouring resin into the hollows of these artefacts to add a more lively colour, this idea becomes stronger.

Archaeologists mosty understand past societies from the material culture. Rare and unique things and monuments are the most impressive artefacts, which convey essential information for understanding the organisation of past societies. We think that in our region the first and earliest barrows (such as at Wiskiauten-Kaup), where the dead were buried from the Late Neolithic to the very end of the Bronze Age, could be the makers of the transition from the Neolithic to the Bronze Age, and from hunting, fishing and gathering to animal husbandry (Gimbutienè 1958, pp. 25-26). Because of the rarity, specific construction and technical quality of boat-axes and amber discs with cruciform decoration, certain objects became effective and novel, and took on a special value. When we talk about amber discs, they were buried first and foremost with individuals who may have been regarded by their community as guard- 


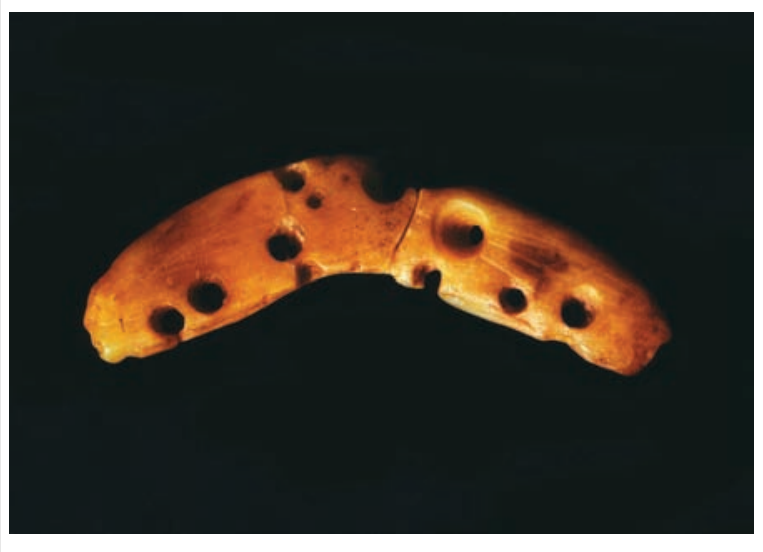

Fig. 17. An amber half-moon pendant from the Šventoji 23 settlement (photograph by A. Baltenas).

ians of such prestigious attributes, and whom data from ethnographic material frequently refers to as having knowledge, special powers, courage or prodignity, and supernatural powers. Prestigious objects find their way into graves or hoards in various ways, depending on the epoch, region, culture and beliefs. These grave goods or hoards differ in content, both quantitatively and qualitatively. They might be single objects, only one item (such as one cruciform-decorated disc), or several (comprising a few or more than a dozen items, such as discs with boat-axes from Būtinge 2 and Groß Morino, discs with another piece of amber jewellery from Wąbrzeźno, and so on). Prestige items have specific qualities: they can be exchanged easily; they can be a quasi-monetary unit, such as amber during the Neolithic period; they had to have a value as a piece of wealth, and be a measure of wealth and standards. In order for this 'commercial' value to be guaranteed, they had to have an agreed value within a large region so that they might be exchanged easily. It is especially clear when discussing the subject of our study that such prestige items might be symbolic objects that would be placed in the graves of the most important (powerful) members of the community as sacrifices to supernatural forces or symbols encoding a certain cultural memory. These symbols, undoubtedly accompanied by oral transmission of traditions, permitted past societies to convey complex ideas over quite a long period of time, as we can deduce from the broad chronology (at least a millennium) of the use of amber discs with cruciform decoration. Artefacts such as discs could be a material expression of these rituals capable of awakening an expression of the past that was 'suppressed' within them (Metzner-Nebelsick 2010, pp. 177-197). Their particularly long development, crossing over cultural periods and cultural boundaries, undoubtedly represents important cultural aspects of the Neolithic

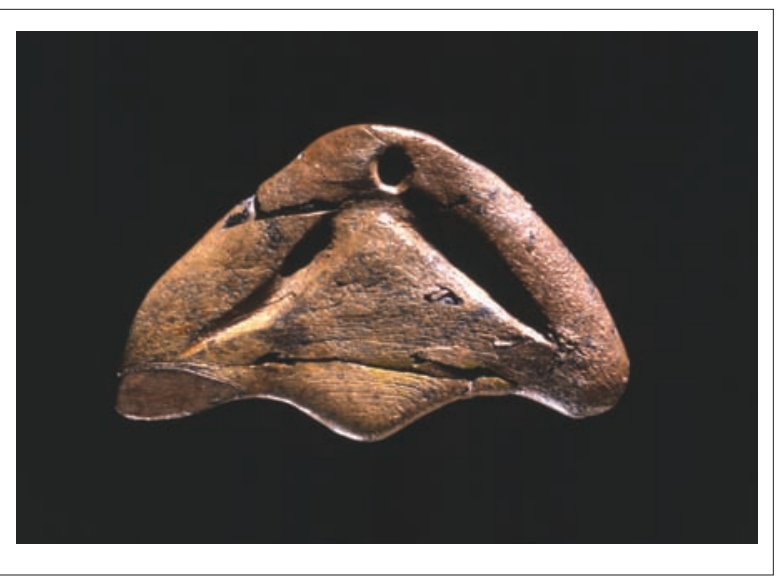

Fig. 18. A bone half-moon pendant from the Kretuonas $1 \mathrm{C}$ settlement (A. Girininkas' investigations).

period, and they are important symbols of the cultural memory.

Discs: between the sun and the moon, the mysteries of light and dark

The Neolithic period was a transition to new forms of economy and new ways of counting time. Throughout Europe, at least from the third millennium BC, the marking of the summer and winter solstices became important; communities living in western Europe at that time developed particularly active formations of earth and stone constructions, and the synchronisation of the solar and lunar calendars became an important, albeit not easy, task for these people (Figs. 17, 18). I can see the significance of these searches in our region in the iconography of amber discs with cruciform decoration.

Without doubt, we cannot regard these ornamental systems as having a purely aesthetic motivation, as objects with only an aesthetic impulse. They were meant for depicting various signs, or visualising the explanation of various rational and not completely rational meanings, and creating associations (David 2010, p. 439). We should note that in Globular-Amphora culture and its zone of influence, or rather the zone of influence of its range of ideas, we come across an area of common ornamental motifs. These are mostly symbols connected with the sun, and some have symbols typical of the sign of the moon. The turning symmetry of these discs, the number of broken lines and hollows, which increases in one direction, evokes ideas of the cyclical path of the sun, sunrise and sunset. Students of European religion at the end of the Neolithic and the Bronze Age connect the period with the cult of the sun, and the sun becomes the main central cult dominant. At the

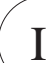

STONE AGE IN NORTHERN EUROPE: CHANGES IN LANDSCAPE, TECHNOLOGIES AND BELIEFS 


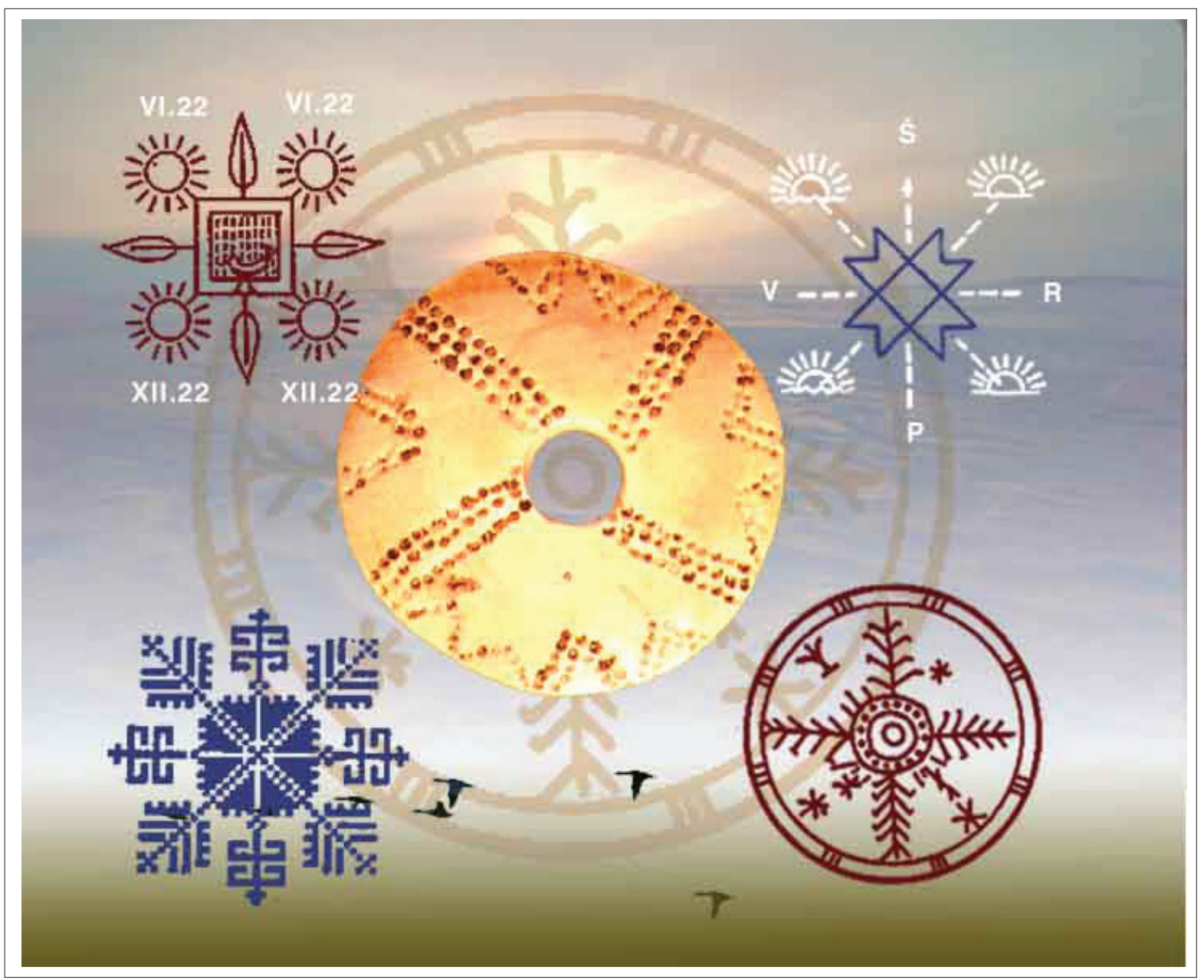

Fig. 19. Amber discs and the winter-summer solstice (compiled by A. Makovska).

same time, we can see that the Daktariške 5 disc and the disc from Ivanje have iconographic motifs on both sides. Perhaps other discs had a similar composition, but unfortunately their state of preservation does not allow us to see this and what they might mean, what different ideas they might represent. In many cases, the analysis of such discs or solar discs leads researchers to hypothesise that both sides are associated with the sun and the moon (Sommerfeld 2010, pp. 537-540). Undoubtedly the mystery of the change from light to dark and black was important to people at that time. It is interesting that when analysing the Daktariške 5 disc on one side, we repeatedly see the number 25 , and the number 8 on the other. We find the same numbers on the Trumdholm solar disc (Sommerfeld 2010, p. 538 , Figs. 1, 2). The repetition of particular numbers in ritual contexts, or objects intended for them, indicates that the people who made and used the discs decorated with a cross and triangles followed a calendar, counted, and were able variously to compute, and this permitted them to organise and check on the world around them, and to establish the cyclical nature of the movement of the sun and moon. These discs were both symbols of a high social status and a way of establishing the time of calendar holy days: harbingers of the great midsummer and midwinter festivals (Fig. 19).

\section{Conclusions}

Almost 40 amber discs decorated with a cross were found in graves and settlements of Globular-Amphora, Zlota and Bay Coast (Rzucewo) cultures. By mapping the cruciform-decorated discs, we can recognise the northern boundary, from the settlements of Būtinge and Šventoji in the northeast to Slupsk in northern Poland. The southern boundary of their distribution is southern Poland and northwest Ukraine. The period for finding amber discs with cruciform decoration in all cultures extends for more than a thousand years, between 3300 and 2000 cal BC. The results obtained from analysing the disc from the Daktariške 5 settlement with FTIR and micro FT-Raman spectroscopy detected a resin mixture in the decoration pits and red clay in the scratches. The placing of these artefacts in 
graves, and the fact that they were found decorated with various quite complex geometric systems, leads us to the conclusion that they were connected with religion, and conceal some essential information about social organisation, calendar or ideological phenomena that may be associated with Neolithic societies.

\section{Acknowledgements}

This research was funded by the Lithuanian Research Council, project No MIP-036/2015.

The authors are very grateful to Dr Ieva Matulaitiene for conducting the micro FT-Raman spectroscopy analysis.

\section{References}

BRODY, R.H., EDWARDS, H.G.M., POLLARD, A.M., 2001. A Study of amber and copa samples using FT-Raman spectroscopy. Spectrochimica Acta Part A, 57, 1325-1338.

DAVID, W., 2010. Die Zeichen auf der Scheibe von Nebra und das altbronzezeitliche Symbolgut des MitteldonauKarpatenraumes. In: H., MELLER, F., BERTEMES, eds. Der Griff nach den Sternen Wie Europas Eliten zu Macht und Reichtum kamen. Internationales Symposium in Halle (Saale) 16.-21. Februar 2005. Tagungen des Landesmuseums für Vorgeschichte Halle (Saale), 5. Halle, 439-486.

EDWARDS, H.G.H., FARWELL, D.W., 1996. Fourrier transform-Raman spectroscopy of amber. Spectrochimica Acta Part A, 52, 1119-1125.

EDWARDS, H.G.H., FARWELL, D.W., VILLAR, S.E.J., 2007. Raman microspectroscopic studies of amber resins with insect inclusions. Spectrochimica Acta Part A, 68, 1089-1095.

FONT, J., SALVADO, N., BITI, S., ENEICH, J., 2007. Fourier transform infrared spectroscopy as a suitable technique in the study of the materials used in waterproofing of archaeological amphorae. Analytica Chimica Acta, 598, 119-127.

FROST, R.L., 1995. Fourier transform Raman spectroscopy of kaolinite, dickite and halloysite. Clays and Clay Minerals, 43, 191-195.

FROST, R.L., FREDERICKS, P.M., BARTLETT, J.H., 1993. Fourier transform Raman spectroscopy of kandite clays. Spectrochimica Acta, 49, 667-674.

FROST, R.L., SHURVELL, H.F., 1997. Raman microprobe spectroscopy of halloysite. Clays and Clay Minerals, 45, 68-72.

GIMBUTIENĖ, M., 1958. Rytprūsių ir Vakarų Lietuvos priešistorinès kultūros apžvalga. Studia Lituanica 1, Mažoji Lietuva, New-York, 11-121, 291-294, 313-316.

KEMPISTY, E., 1971. Kultura amfor kulistych na Mazowszu i Podlasiu. Materialy Starożytne i wczesnośredniowieczne, $1,7-34$.

KILIAN, L., 1955. Haffküstenkultur und Ursprung der Balten. Bonn

KLEBS, R., 1882. Der Bernsteinschmuck der Steizeit von der Baggerei bei Schwarzort und anderen Lokalitäten Preussens. Königsberg.

KRZAK, Z., 1976. The Zlota culture. Wrocław.
LA BAUME, W., 1943. Die jungsteinzeitliche Kugelamphoren-Kultur in Osst und West Preußen. Prussia, 35, 13-80.

LETTIERI, M., 2015. Infrared spectroscopic characterization of residues on archeological pottery through different spectra acquisition modes. Vibrational Spectroscopy, 76, $48-54$.

Loze, I., 1979. Pozdnii neolit i ranniaia broza Lubanskoi ravniny. Riga.

METZNER-NEBELSICK, C., 2010. Die Ringe der Macht Überlegungen zur Kontinuität frühbronzezeitlicher Herrschaftssymbole in Europa. In: H., MELLER, F., BERTEMES, eds. Der Griff nach den Sternen Wie Europas Eliten zu Macht und Reichtum kamen. Internationales Symposium in Halle (Saale) 16.-21. Februar 2005. Tagungen des Landesmuseums für Vorgeschichte Halle (Saale), 5. Halle, 179-197.

OKULICZ, I., 1973. Pradzieje ziem pruskich od póżnego paleolitu do VI w. n. Wrocław.

RIMANTIENĖ, R., 1996. Akmens amžius Lietuvoje. Vilnius. RIMANTIENĖ, R., 2005. Die Steinzeitfischer an der Ostseelagune in Litauen. Vilnius.

SATHYA, P., VELRAJ, G., 2011. FTIR spectroscopic and $\mathrm{X}$-ray diffraction analysis of archaeological grey potteries excavated in Alagankulam, Tamil Nadu, India. Journal of Experimental Sciences, 2, 2-4.

SHILLITO, L.M., ALMOND, M. J., WICKS, K., 2009. The use of FT-IR as a screening technique for organic residue analysis of archeological samples. Spectrochimica Acta Part A, 72, 120-125.

SOCRATES, G., 2001. Infrared and Raman characteristic group frequencies. Chichester.

SOMMERFELD, C., 2010. Sommerfeld Die KehrseiteAnmerkungen zur Rolle des mondes in der ikonographie der Bronzezeit. In: H., MELLER, F., BERTEMES, eds. Der Griff nach den Sternen Wie Europas Eliten zu Macht und Reichtum kamen. Internationales Symposium in Halle (Saale) 16.-21. Februar 2005. Tagungen des Landesmuseums für Vorgeschichte Halle (Saale), 5. Halle, 537-550.

ŠTURMS, E., 1956. Der Bernsteinschmuck der östlichen Amphorenkultur. Rheinische Forschungen zur Vorgeschichte, 5, 13-20.

SVESHNIKOV, I.K., 1983. Kul'tura sharovidnykh amfor. Arkheologiia SSSR. Svod arkhelogicheskikh istochnikov. Vyp. B1-27, Moskva.

SZMYT, M., 1999. Between West and East. People of the Globular Amphora Culture in Eastern Europe 2950-2350 $B C$. Poznan.

VANDENABEELE, P., GRIMALDI, D.M., EDWARDS, H.G.H., MOENS, L., 2003. Raman spectroscopy of different types of Mexican copal resins. Spectrochimica Acta Part A, 59, 2221-2229.

VANDENABEELE, P., WEHLING, B., MOENS, L., DE REU, M., VAN HOOYDONK, G., 2000. Analysis with micro-Raman spectroscopy of natural organic binding media and varnishes used in art. Analytica Chimica Acta, 400, 261-274.

VENKATACHALAPATHY, R., GOURNIS, D., MANOHARAN, C., DHANAPANDIAN, S., DEENANADAYALAN, K., 2003. Application of FTIR and Mossbauer spectroscopy in analysis of some South Indian archaeological potteries. Indian journal of pure \& applied physics, 41, 833-838.

WISLANSKI, T., 1966. Kultura amfor kulistych $w$ Polsce pótnocno-zachodniej. Wrocław.

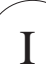

STONE AGE IN NORTHERN EUROPE: CHANGES IN LANDSCAPE, TECHNOLOGIES AND BELIEFS 
Adomas Butrimas

Institute of Art Research

Vilnius Academy of Art

Dominikonų St 15, LT-01131 Vilnius, Lithuania

E-mail: adomas.butrimas@vda.1t

Regina Ulozaitè

National Museum of Lithuania

Arsenalo 1, LT-01143 Vilnius, Lithuania

E-mail: regina.ulozaite@lnm.lt

Marius Iršènas

Institute of Art Research

Vilnius Academy of Art

Dominikonų St 15, LT-01131 Vilnius, Lithuania

E-mail:marius.irsenas@vda.lt

GINTARO SKRIDINIAI,

DEKORUOTI KRYŽMOMIS

\section{ADOMAS BUTRIMAS, \\ REGINA ULOZAITÉ, MARIUS IRŠE்NAS}

\section{Santrauka}

Gintaro skridiniai, dekoruoti išgręžtomis duobutemis, kurios sudaro kryžiaus motyvą, kartais papildytą trikampiais motyvais, buvo paplitę rutulinių amforų, Zlotos ir Pamarių kultūrose nuo 3300 iki 2000 cal BC. Labai gerai išsilaikęs skridinys, net su organinès medžiagos pèdsakais jo ornamente, rastas Daktariškès 5-ojoje neolito gyvenvietejje, Vakarų Lietuvoje.

Siekiant nustatyti tamsios medžiagos skridinio duobutėse ir rausvų likučių įbraižose kilmę, buvo atlikta Furjè (Fourier) transformacijos infraraudonujų spindulių (FTIR) ir Furje transformacijos - Ramano (FT-Raman) mikrospektrinè analizè. Iš gautų rezultatų matyti, kad tamsiai ruda medžiaga gali būti spygliuočių dervos, sakų ir bičių vaško mišinys, o kitoje pusejje esančiose ịbraižose - raudono molio likučiai.

Spalvinis duobučių ornamento išryškinimas leidžia kelti hipotezę apie ypatingą, simbolinę, gintaro skridinių reikšmę, galbūt statuso simbolį. Duobučių skaičius ir trikampių figūrų išdėstymas tarp kryžmų gali rodyti kalendorinę skridinio iš Daktariškès 5-osios gyvenvietès reikšmę. 